\title{
Dinoflagellate cysts from the Szlachtowa Formation (Jurassic) and adjacent deposits (Jurassic-Cretaceous) of the Grajcarek Unit at Szczawnica-Zabaniszcze (Pieniny Klippen Belt, Carpathians, Poland)
}

\author{
Przemysław GEDL ${ }^{1, *}$ \\ 1 Institute of Geological Sciences, Polish Academy of Sciences, Senacka 1, 31-002 Kraków, Poland
}

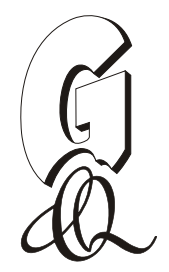

Gedl P. (2013) Dinoflagellate cysts from the Szlachtowa Formation (Jurassic) and adjacent deposits (Jurassic-Cretaceous) of the Grajcarek Unit at Szczawnica-Zabaniszcze (Pieniny Klippen Belt, Carpathians, Poland). Geological Quarterly, 57 (3): 485-502, doi: doi: 10.7306/gq.1106

\begin{abstract}
The Jurassic-Cretaceous fine-clastic dark deposits of the Grajcarek Unit (Pieniny Klippen Belt, Carpathians, Poland) show lithological similarities, which may lead to erroneous age correlations. Their well-exposed outcrop at Szczawnica-Zabaniszcze allows detailed sampling for their precise age determination. For this purpose, dinoflagellate cysts have been studied from a set of samples collected from the Szlachtowa, Opaleniec, Pieniny Limestone, Kapuśnica and Wronine formations exposed at that site (additional sample from the Pieniny Limestone Formation was studied). The Szlachtowa Formation, a very characteristic lithostratigraphic unit, which consists of black shale and sandstones extremely rich in mica flakes, occasionally referred to literature as the so-called "black flysch", yielded rich and well-preserved assemblages. Their age is Middle Jurassic, spanning the Aalenian to Lower Bajocian. The exposures of the Szlachtowa Formation at Szczawnica-Zabaniszcze are located close to the outcrops of the Opaleniec Formation. The calcareous spotted shale from this lithostratigraphic unit yielded rich dinoflagellate cyst assemblage characteristic for Late Bathonian (Early Callovian?). The Opaleniec Formation tectonically contacts with very similar non-calcareous spotted shale of the Wronine Formation. Its age, based on infrequent dinoflagellate cysts is Aptian-Albian. Similar, Lower Aptian age was concluded for the Kapuśnica Formation. Late Barremian-earliest Aptian dinoflagellate cysts have been found in the underlying topmost part of the Pieniny Limestone Formation.
\end{abstract}

Key words: Szlachtowa Formation, "black flysch", biostratigraphy, Jurassic, Cretaceous, Pieniny Klippen Belt.

\section{INTRODUCTION}

The Szlachtowa Formation is a lithostratigraphic unit described by Birkenmajer (1977). It occurs in the klippen successions of the Pieniny Klippen Belt (except in the Czorsztyn Succession) and in the Magura Nappe, tectonically incorporated into the Pieniny Klippen Belt structure (known as the Grajcarek Unit; Birkenmajer, 1977, 1986). In the latter unit it reaches a maximum thickness of over $220 \mathrm{~m}$, and is widely distributed there. The Szlachtowa Formation consists of dark-coloured (black to dark grey) flysch deposits including calcareous shale and very characteristic sandstone layers with abundant mica flakes; the latter occur extensively in shaly mudstone, being less frequent in clay shale. The dark colour of these flysch deposits led early researchers to the conclusion that they were Cretaceous in age, by comparison with black flysch and flyschoid Cretaceous strata of the Outer Carpathians (e.g. Uhlig, 1890). But, later findings of Jurassic macrofossils suggested a Middle Jurassic age for these strata (e.g., Andrusov, 1929, 1938). Discussion of the age of the Szlachtowa Forma-

\footnotetext{
* E-mail address: ndgedl@cyf-kr.edu.pl
}

Received: March 5, 2013; accepted: May 20, 2013; first published online: June 27, 2013 tion was renewed by Sikora (1962; see also 1971) who suggested a Cretaceous age for this unit. This age-interpretation was, however, undermined by further evidence of Middle Jurassic age, mainly microfossils, in the Szlachtowa Formation (e.g., Birkenmajer and Pazdro, 1968; Birkenmajer et al., 1970; Pazdro, 1979; Dudziak, 1986). The problem of the age of the Szlachtowa Formation was once again raised by Oszczypko et al. (2004) who opted for a Cretaceous age. This view was criticized by Birkenmajer et al. (2008). Despite the latest results of micropalaeontological studies showing an undoubted Middle Jurassic age for the deposits in question (e.g., Gedl, 2008d), Oszczypko et al. (2012) presented their opposing interpretation (see also Barski et al., 2012). Because the results of their studies are, in my opinion, based on erroneously collected material, I sampled the exposure of the Szlachtowa Formation and adjacent units at Szczawnica-Zabaniszcze, which was also investigated by those authors. The results of the present studies and comparison with earlier studies are given in this paper.

\section{GEOLOGICAL SETTING}

The Pieniny Klippen Belt forms a narrow structure at the boundary with the Outer Carpathians separating it from the Inner Carpathians (Fig. 1A). This structure, over $600 \mathrm{~km}$ long and from 1 to $20 \mathrm{~km}$ wide, was formed during the Laramian orogeny when the Tethyan Upper Triassic-Cretaceous succession was 


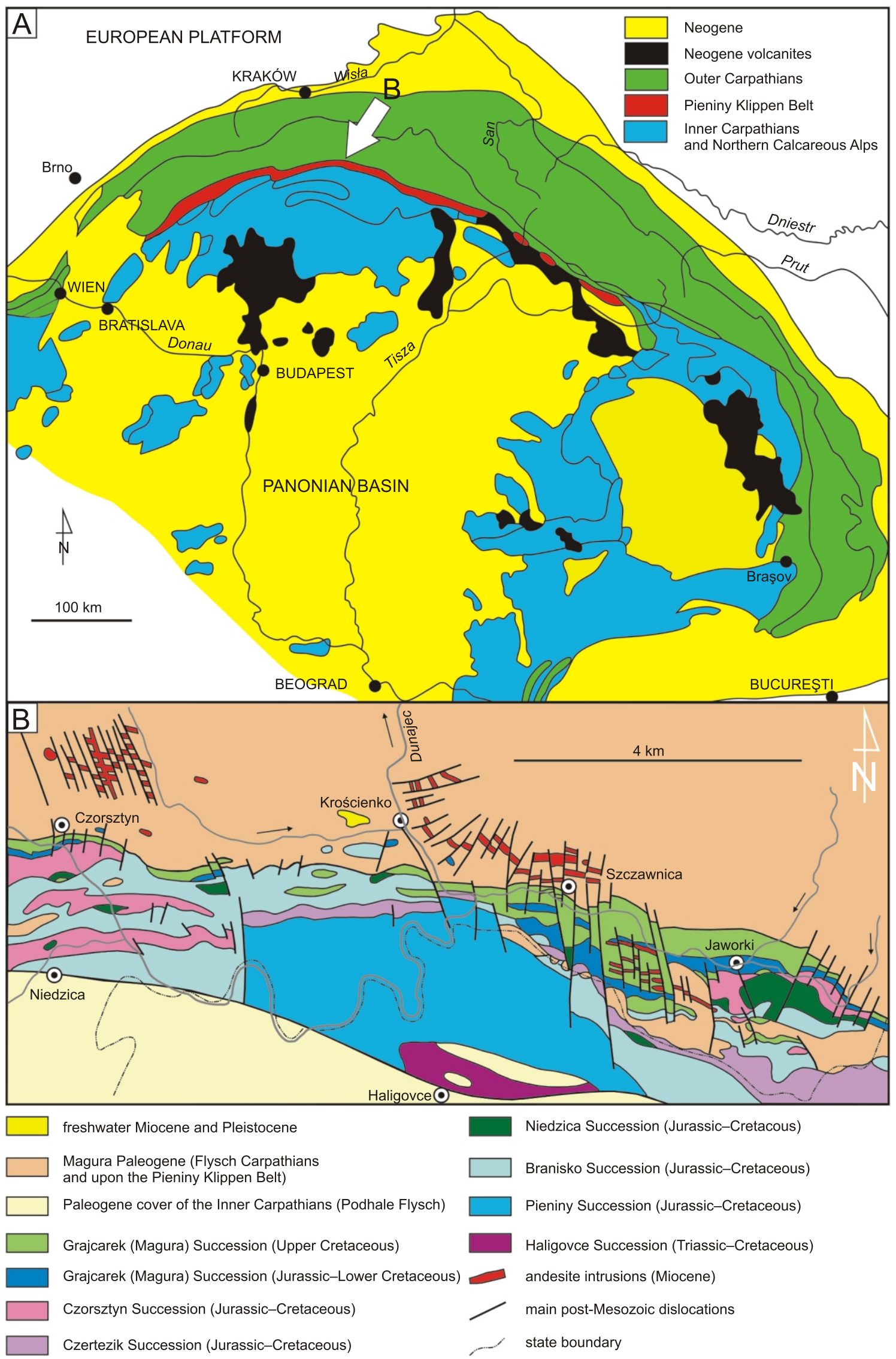

Fig. 1. Geological maps of the Carpathians (A) and the eastern sector of the Pieniny Klippen Belt in Poland (B; from Birkenmajer, 1977) 
Outer

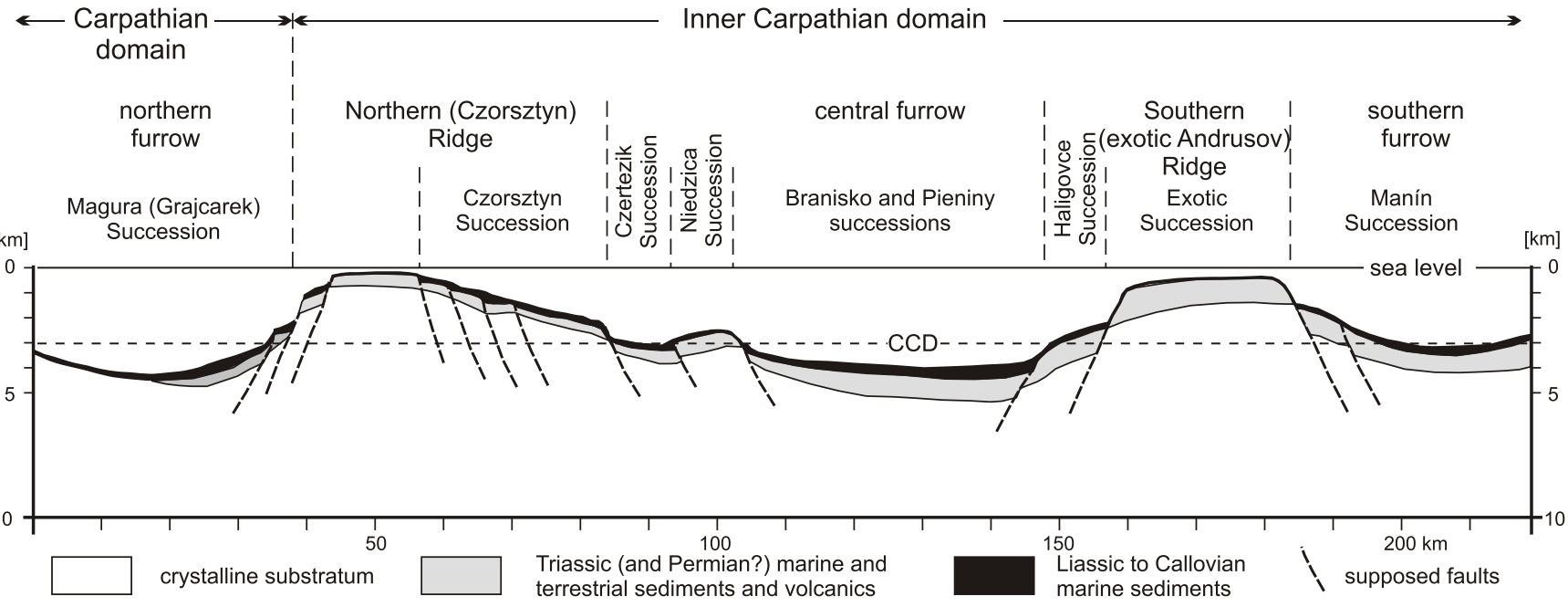

Fig. 2. Palinspastic reconstruction of the Pieniny Klippen Belt Basin and the southern part of the Magura Basin during the Callovian (from Birkenmajer, 1977)

CCD - carbonate compensation depth

folded, overthrusted and squeezed between the North European Platform and northwards migrating African plates. Birkenmajer (1977), in the Polish sector, distinguished five successions, from basinal (Pieniny and Branisko successions), through transitional (Niedzica, Czertezik) to the shallowest one located on the Czorsztyn Ridge, which limited the Pieniny basin system from the north. It separated the Pieniny basins from the Magura Basin of the Outer Carpathian domain, which existed during the Jurassic-Cretaceous (Fig. 2). A part of the Magura Succession, known as the Grajcarek Unit, was incorporated into the Pieniny Klippen Belt system during the Laramian orogeny (Birkenmajer, 1977). The Grajcarek Unit succession starts with the Szlachtowa Formation (dark-coloured shaly flysch of Middle Jurassic age) representing the oldest phase of the Magura Basin development (Fig. 3). Gradual deepening of the basin is reflected by appearance of the Fleckenmergel facies (the Opaleniec and Stembrow formations), which passes into Middle-Upper Jurassic radiolarian deposits (the Sokolica Radiolarian Formation, the Czajakowa Radiolarian Formation) overlain by Upper Jurassic-Lower Cretaceous pelagic limestone (Czorsztyn Limestone Formation and Pieniny Limestone Formation). A mid-Cretaceous bottom oxygen-depleted phase is reflected by dark-coloured fine-grained deposits of the Kapuśnica, Wronine and Hulina formations. An interval of well-oxygenated pelagic sedimentation (Late Cretaceous) is reflected by deposition of predominantly red-coloured clay (the Malinowa Shale Formation) followed by Upper Cretaceous flysch-facies (Hałuszowa Formation). The Laramian orogenic phase, responsible for incorporation of the Grajcarek Unit into the Pieniny Klippen Belt, is manifested by deposition of the coarse-grained conglomerates of the Jarmuta Formation (Maastrichtian).

\section{MATERIAL}

The exposures studied at Szczawnica-Zabaniszcze crop out in a small tributary of the Grajcarek Creek (Jarmucki Potok vel Zabaniszcze Stream), just behind an old house (Fig. 4; see also Oszczypko et al., 2012: fig. 4C). It is located near the classic site of a condensed succession of the Grajcarek Unit exposed several tens of metres downstream, along the southern bank of Grajcarek Creek (see e.g., Birkenmajer, 1977). Thick-bedded conglomerates of the Jarmuta Formation form a distinct morphological threshold in the stream bed, some $80 \mathrm{~m}$ from the junction with the Grajcarek Creek (GPS coordinates:

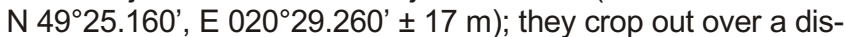
tance of 5-6 metres (Fig. 5A). Vertically dipping strata of the Jarmuta Formation pass into the red shale of the Malinowa Shale Formation (some $150 \mathrm{~cm}$ ), which are in tectonic contact with the vertically dipping Middle Jurassic Sokolica Radiolarite Formation (ca. $6 \mathrm{~m}$; Fig. 5A, B). The latter passes into the Czajakowa Radiolarite Formation and the Pieniny Limestone Formation; both lithostratigraphic units form a small klippe (Fig. 5A, C). The uppermost part of the Pieniny Limestone Formation consists of dark grey to black limestone with intercalations of cherty limestone and black calcareous shale (the latter lithology was sampled - SzZ27; Fig. 5A). It passes into 80-110 cm thick black and dark olive spotted, partly siliceous, calcareous shale of the Kapuśnica Formation (sample SzZ28 was collected $30 \mathrm{~cm}$ above the top of the Pieniny Limestone Formation). Farther to the SE, the Kapuśnica Formation passes into willow green to dark green and blackish spotted non-calcareous clay shale attributed by Birkenmajer (1977) to the Wronine Formation (Fig. 5A; see also Oszczypko et al., 2012: fig. 4C), which crops out over a distance of ca. $80-100 \mathrm{~cm}$ (there are no farther exposures on this creek bank - being covered with black muddy weathered material, presumably from the Szlachtowa Formation, washed from higher parts of the slope). Sample SzZ29 was collected from the basal part of the Wronine Formation, $50 \mathrm{~cm}$ above sample SzZ28 (Fig. 5A).

Further outcrops of the Grajcarek Unit are well-exposed on the opposite (northeastern) bank of the creek (Fig. 5D). Here, the succession starts with the Pieniny Limestone Formation (there is a slickenside on its top; Fig. 5E). The overlying Kapuśnica Formation is tectonic reduced here to merely $10-30 \mathrm{~cm}$ of thickness (dark greenish and black calcareous shale with lenses of silicified shale: sample SzZ30A is soft, 


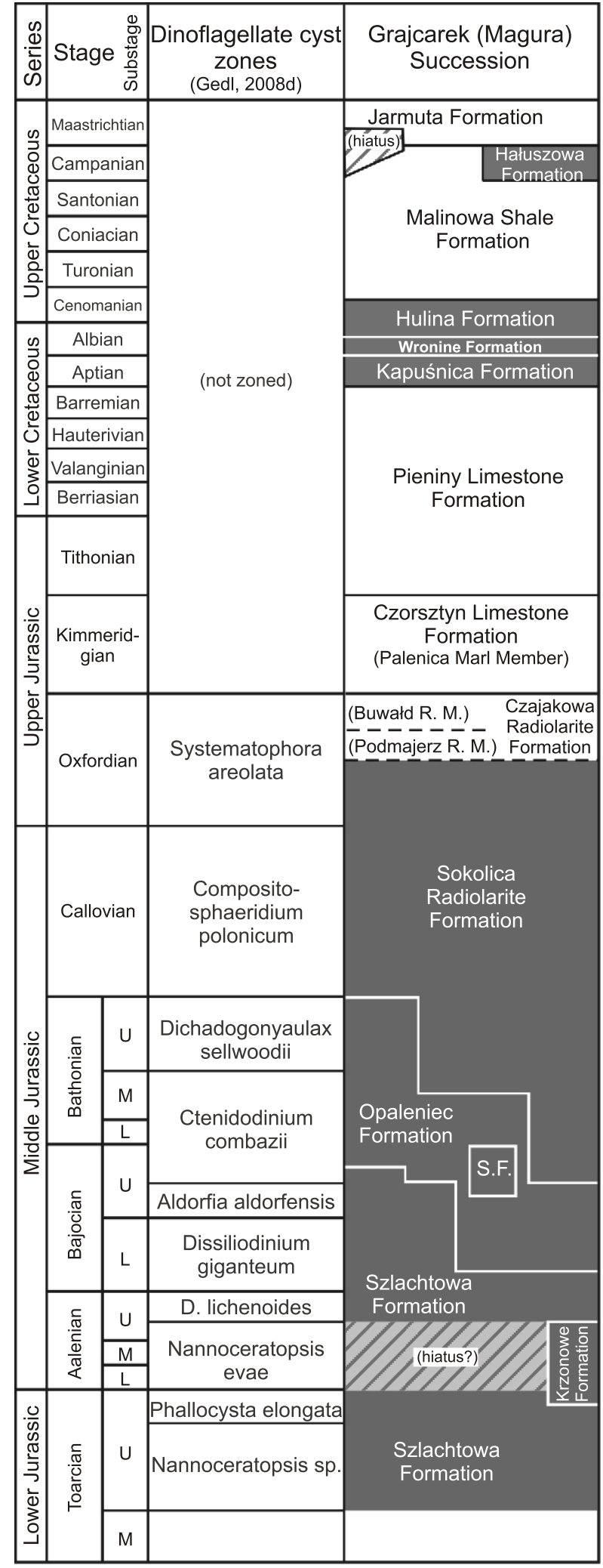

Fig. 3. Lithostratigraphic division of the Grajcarek Unit (based on Birkenmajer, 1977, modified in the Aalenian-Bathonian part by Gedl, 2008d)

R. M. - Radiolarite Member; S. F. - Stembrow Formation

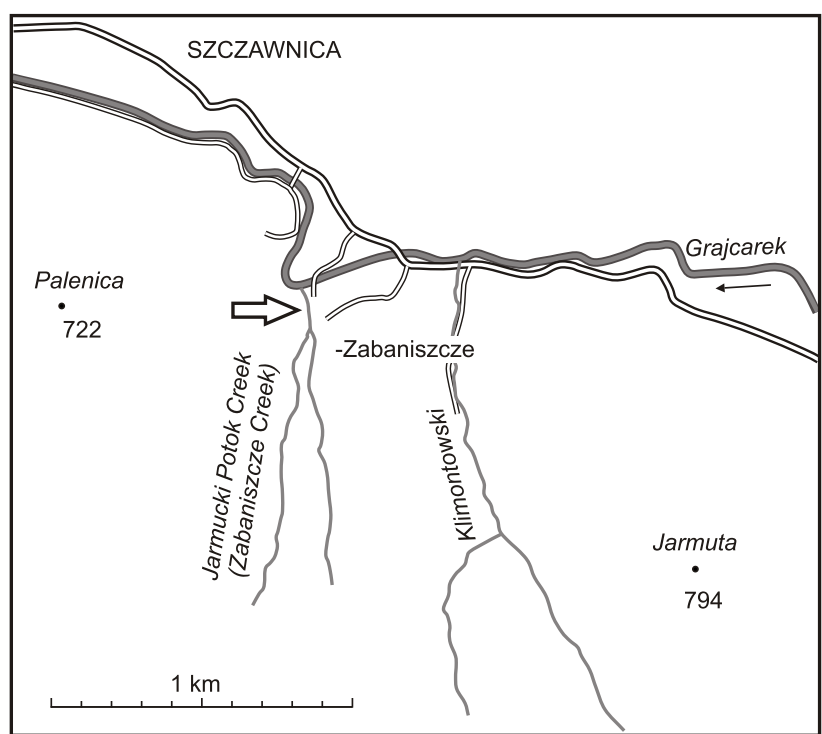

Fig. 4. Location of the section studied at Szczawnica-Zabaniszcze (arrowed)

highly weathered, pale greenish-grey, calcareous clay shale, and SzZ30B is hard, black, silicified, highly calcareous, cubic-fracturing shale; Fig. 5D, E). The Kapuśnica Formation, as on the opposite creek bank, passes into non-calcareous greenish massive clay shale with black spots and the black (manganiferous) and rusty (ferruginous) weathering coating of the Wronine Formation, which dips $40-50^{\circ} \mathrm{SE}$ (Fig. 5D, E). Samples SzZ31-33, representing the Wronine Formation, were collected in the following positions: SzZ31 $-5 \mathrm{~cm}$ from the SzZ30, just from the basal part of the Wronine Formation; SzZ32 - $60 \mathrm{~cm}$ from the top of the Pieniny Limestone Formation; red shale layers occur between SzZ31 and SzZ32 (Fig. 5D, E). Sample SzZ33, collected $50 \mathrm{~cm}$ from SzZ32, represents a calcareous greenish spotty massive shale. Starting from sample SzZ33 strata dip at a lower angle (ca. $30^{\circ} \mathrm{SE}$ ). Farther, non-calcareous spotted shale with thin (under $1 \mathrm{~cm}$ ) black lamina occur (SzZ34 - $70 \mathrm{~cm}$ from SzZ33).

Sample SzZ35 was taken $100 \mathrm{~cm}$ farther, from calcareous fine-splitting shale. $70 \mathrm{~cm}$ farther, a clear tectonic boundary occurs: the outcrop is cut at $30-40^{\circ}$ by an overthrust of pale-grey calcareous fine-splitting shale (samples SzZ36, SzZ37 and SzZ38 were taken very close to each other from the overthrust: the first one from the NW part, two others from the SE part; Fig. 5D, F). Pale grey calcareous fine-splitting shale that occurs close to the overthrust is highly tectonized; no clear bedding is visible. Bedding is seen some $30-40 \mathrm{~cm}$ from the overthrust showing vertical dip (SzZ39 - $60 \mathrm{~cm}$ from SzZ36). Farther, at a distance of $3 \mathrm{~m}$ (Fig. 5G), massive greenish spotted, calcareous shale with a rusty coating (similar to the shale that occurs NW of the overthrust; SzZ40, SzZ42) overlies fine-splitting, spotted greyish calcareous shale (SzZ41, SzZ43, SzZ44). Starting from sample SzZ43, shales dip $40-50^{\circ} \mathrm{SE}$. The exposure ends with a small waterfall (Fig. 5D).

There are no exposures on this creek bank for a distance of $12 \mathrm{~m}$ (the opposite bank is covered with slope debris derived from the Szlachtowa Formation shale and sandstones). The next exposure is a small outcrop of the Szlachtowa Formation (black calcareous muddy shale with abundant mica flakes and thin-bedded sandstones: sample SzZ45; Fig. 5D). Its strata dip $45^{\circ} \mathrm{NW}$ (lack of exposure between this and the previous one 

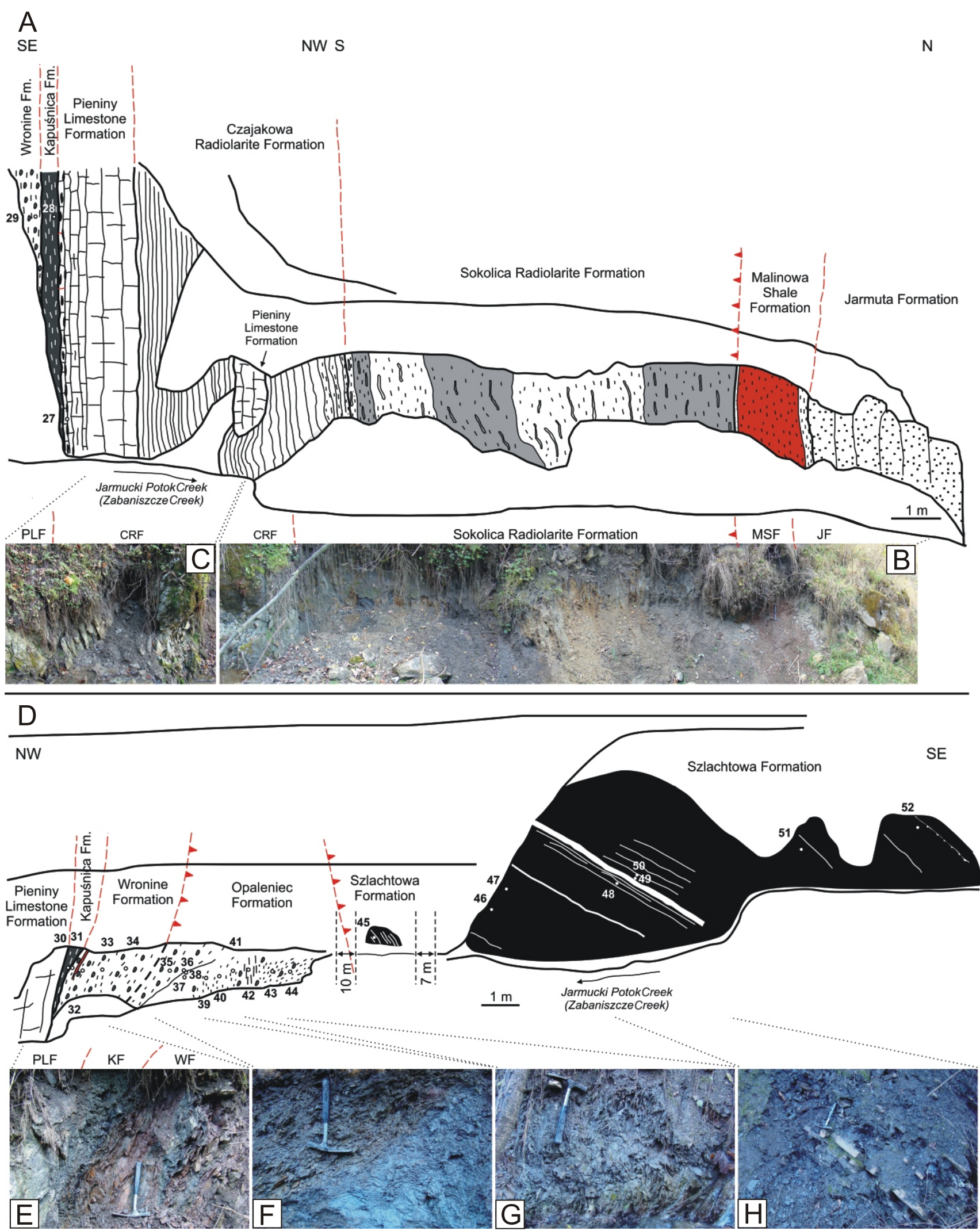

Fig. 5. Exposures of Middle Jurassic-Upper Cretaceous strata of the Grajcarek Unit at Szczawnica-Zabaniszcze

A - exposure on the western bank of the Jarmucki Potok and sample positions; B - photograph of the Jarmuta Formation (JF; right) and the red shale of the Malinowa Shale Formation (MSF) in tectonic contact with the Sokolica Radiolarite Formation and the Czajakowa Radiolarite Formation (CRF; left); C - photograph of the Czajakowa Radiolarite Formation (CRF) and the Pieniny Limestone Formation (PLF); D - exposure on the northeastern bank of the Jarmucki Potok (just above the exposure in A) and sample positions; $\mathbf{E}$ - photograph of the passage from the Pieniny Limestone Formation (PLF; right), tectonically squeezed Kapuśnica Formation (KF) to the spotted shale of the Wronine Formation (WR; note red shale occurrence within the latter); F, G - tectonically disturbed marly shale of the Opaleniec Formation; $\mathbf{H}-\mathrm{NW}$ dipping strata of the Szlachtowa Formation (samples SzZ48-51 were collected near thick sandstone layer close to the hammer); B, C scales as in $\mathrm{A}$; E-I - hammer as a scale $(28 \mathrm{~cm})$ 
does not allow tracing their contact, which, given the differences in dip, seems to be tectonic).

There are no exposures for a farther $8 \mathrm{~m}$ until a large exposure of the Szlachtowa Formation starts in the creek scarp (Fig. 5D). This lithostratigraphic unit is very well-exposed here continuously over a distance of several metres. The Szlachtowa Formation consists here of black calcareous clay and muddy shale, the latter being enriched in mica flakes. Sandstones are rare, usually thin-bedded $(2-4 \mathrm{~cm})$, occasionally thicker up to $20 \mathrm{~cm}$ (Fig. $5 \mathrm{H}$ ). Sole marks on the bottom surfaces of sandstone layers, as well as the continuous passage of sandstone to mudstone, show that this succession lies normally, dipping $40-45^{\circ}$ NW. Six further samples from the Szlachtowa Formation were collected (SzZ46-51; Fig. 5D). All of them represent clayey shale except for sample SzZ49 collected from a $2 \mathrm{~cm}$ thick mudstone just above a $20 \mathrm{~cm}$ sandstone layer.

\section{METHODS}

The samples were processed in the Micropalaeontological Laboratory of the Institute of Geological Sciences, Polish Academy of Sciences, Kraków. The applied standard palynological procedure included $38 \%$ hydrochloric-acid $(\mathrm{HCl})$ treatment, $40 \%$ hydrofluoric-acid (HF) treatment, heavy-liquid $\left(\mathrm{ZnCl}_{2}+\mathrm{HCl}\right.$; density $\left.2.0 \mathrm{~g} \cdot \mathrm{cm}^{-3}\right)$ separation, ultrasound for $10-15 \mathrm{~s}$ and sieving at $10 \mu \mathrm{m}$ on a nylon mesh. No nitric-acid $\left(\mathrm{HNO}_{3}\right)$ treatment was applied.

The quantity of rock processed was $30 \mathrm{~g}$ for each sample. Palynological slides were made from each sample using glycerine jelly as a mounting medium. The rock samples, palynological residues and slides are stored in the collection of the Institute of Geological Sciences, Polish Academy of Sciences, Kraków.

\section{RESULTS}

The Pieniny Limestone Formation. Sample SzZ27 collected from the top of this unit contains palynofacies dominated by black opaque phytoclasts (partly showing dark brown, translucent edges) and dinoflagellate cysts (up to $30 \%$; however, their precise ratio is difficult to determine due to their commonly fragmentary preservation; Fig. 6) dominated by Cerbia tabulata and Oligosphaeridium spp. (Fig. 7).

The Kapuśnica Formation. Palynofacies of samples from this unit are characterized by a high ratio of sporomorphs: over $60 \%$ (mainly spores) in SzZ28 and 25\% (mainly pollen grains) in SzZ30B. Dinoflagellate cyst assemblages vary between samples (Fig. 6). They are relatively rare in SzZ28; the most frequent species is Odontochitina operculata. Samples from the Kapuśnica Formation from the northern creek bank (SzZ30A and SzZ30B) contain assemblages dominated by Valensiella (mainly $V$. reticulata), which in sample SzZ30B form an acme (Fig. 8).

The Wronine Formation. Samples from this lithostratigraphic unit contain a very uniform palynofacies: it is composed almost entirely of black phytoclasts, usually with translucent edges. Cuticles are absent, whereas sporomorphs are represented by spore specimens occurring as two to three specimens per slide; they are well-preserved being dark yellow-brownish. Samples from the Wronine Formation differ slightly in various ratios of aquatic palynomorphs, and in their preservation. Sample SzZ29 yielded only two dinoflagellate cyst specimens (Odontochitinia operculata, ?Hystricho-

\begin{tabular}{|c|c|c|c|c|c|c|c|c|c|}
\hline Lithostratigraphy & 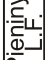 & & $\begin{array}{l}\text { ouśn } \\
\text { mati }\end{array}$ & & & & $\begin{array}{l}\text { onin } \\
\text { mati }\end{array}$ & & \\
\hline Taxon -2 Sample & $\begin{array}{l}\hat{N} \\
\mathbf{N} \\
\omega\end{array}$ & $\begin{array}{l}\infty \\
N \\
N \\
\omega\end{array}$ & $\begin{array}{l}0 \\
\mathbb{N} \\
N \\
N \\
\infty\end{array}$ & $\begin{array}{l}0 \\
\tilde{N} \\
N \\
N \\
\omega\end{array}$ & $\begin{array}{l}\text { N } \\
\text { N } \\
\infty\end{array}$ & $\begin{array}{l}\bar{N} \\
N \\
N\end{array}$ & $\begin{array}{l}\mathcal{N} \\
\tilde{N} \\
\omega\end{array}$ & $\underset{N}{N}$ & $\begin{array}{l}\mathbb{N} \\
N \\
N\end{array}$ \\
\hline Chlamydophorella sp. & $\mathrm{x}$ & & & & & & & & \\
\hline Pterodinium alliferum & $\mathrm{x}$ & & & & & & & & \\
\hline Pterodinium premnos & c & $\mathrm{x}$ & & & & & & & \\
\hline Pterodinium cingulatum & $\mathrm{x}$ & & $x$ & & & & & & \\
\hline Pterodinium sp. & $\mathrm{x}$ & & $x$ & & & & & $\mathrm{x}$ & \\
\hline Rhynchodiniopsis aptiana & $\mathrm{c}$ & $x$ & & & & & & & \\
\hline Tanyosphaeridium regulare & $\mathrm{x}$ & $\mathrm{x}$ & & & & & & & \\
\hline Tanyosphaeridium sp. & $x$ & & & & & & & $x$ & \\
\hline Oligosphaeridium asterigerum & $\mathrm{x}$ & $x$ & & & & & & & \\
\hline Oligosphaeridium complex & $\mathrm{c}$ & $x$ & & $\mathrm{x}$ & & & & & $\mathrm{x}$ \\
\hline Oligosphaeridium albertense & $\mathrm{c}$ & & & & & & & & \\
\hline O. complex brevispinum & $\mathrm{x}$ & & & & & & & & \\
\hline Oligosphaeridium sp. & $\mathrm{x}$ & & & $\mathrm{x}$ & & & $x$ & & \\
\hline Prolixosphaeridium parvispinum & c & c & $\mathrm{x}$ & & & & $\mathrm{x}$ & & \\
\hline Ellipsodinium reticulatum & $\mathrm{x}$ & & & & & & & & \\
\hline Cerbia tabulata & $\mathrm{c}$ & & & $\mathrm{x}$ & & & $\mathrm{x}$ & & \\
\hline Dapsilidinium multispinosum & $\mathrm{x}$ & $x$ & $\mathrm{x}$ & $\mathrm{x}$ & & & & & \\
\hline Subtilisphaera sp. & $\mathrm{x}$ & & & & & & & & \\
\hline Spiniferites ramosus & $\mathrm{x}$ & $x$ & & $\mathrm{x}$ & & & & & \\
\hline Spiniferites spp. & $\mathrm{x}$ & $x$ & & $\mathrm{x}$ & & & & $x$ & \\
\hline Escharisphaeridia sp. & $\mathrm{x}$ & & & & & & & & \\
\hline Batiacasphaera spp. & $\mathrm{x}$ & & & a & & & & & \\
\hline Lithodinia stoveri & $x$ & & & & & & & & \\
\hline Kiokansium sp. & $x$ & $x$ & $x$ & & & & & $x$ & \\
\hline Cometodinium habibii & $\mathrm{x}$ & & & & & & & & \\
\hline Mendicodinium sp. & & $x$ & & $\mathrm{x}$ & & & & & \\
\hline Odontochitina operculata & & $c$ & & $\mathrm{x}$ & $x$ & $x$ & $x$ & $x$ & \\
\hline Odontochitina imparilis & & $x$ & & & & & & & \\
\hline Tehamadinium sp. & & c & & & & & & & \\
\hline Chytroeisphaeridia sp. & & $x$ & & & & & & & \\
\hline Valensiella reticulata & & $c$ & $\mathrm{a}$ & & & & & & \\
\hline Druggidinium? sp. & & $c$ & & & & & & & \\
\hline Heslertonia heslertonensis & & $x$ & & & & & & & \\
\hline Circulodinium distinctum & & $x$ & & & & & & & \\
\hline Gonyaulacysta? kleithria & & $\mathrm{x}$ & & & & & & & \\
\hline Gonyaulacysta sp. & & $x$ & & & & & & & \\
\hline Diphasiosphaera stolidata & & $x$ & & & & & & & \\
\hline Exiguisphaera plectilis & & $x$ & & & & & & & \\
\hline Protoellipsodinium? sp. & & $x$ & $x$ & $\mathrm{x}$ & & & & & \\
\hline Aptea securigera & & $x$ & & & & & & & \\
\hline Taleisphaera hydra & & $\mathrm{x}$ & & & & & & & \\
\hline Dapsilidinium warrenii & & $x$ & & & & & & $x$ & \\
\hline Kleithriasphaeridium sp. & & $x$ & & & & & & & \\
\hline Wallodinium krutzschi & & $x$ & & & & & & & \\
\hline Valensiella spp. & & & c & A & & & & & \\
\hline Circulodinium sp. & & & $\mathrm{x}$ & & & & & $x$ & $\mathrm{x}$ \\
\hline Cribroperidinium sp. & & & & $\mathrm{x}$ & & & & & \\
\hline ?Hystrichosphaeridium ?phoenix & & & & & $x$ & & & & \\
\hline Dinogymnium? sp. & & & & & & & $a$ & & \\
\hline Su & & & & & & & & X & \\
\hline
\end{tabular}

Fig. 6. Dinoflagellate cyst distribution in the Pieniny Limestone Formation, the Kapuśnica Formation and the Wronine Formation at Szczawnica-Zabaniszcze

$\mathrm{x}$ - single to rare; $\mathrm{c}$ - frequent (10-50 specimens); $\mathrm{a}$ - abundant (over 50 specimens); A - mass occurrence (acme) 

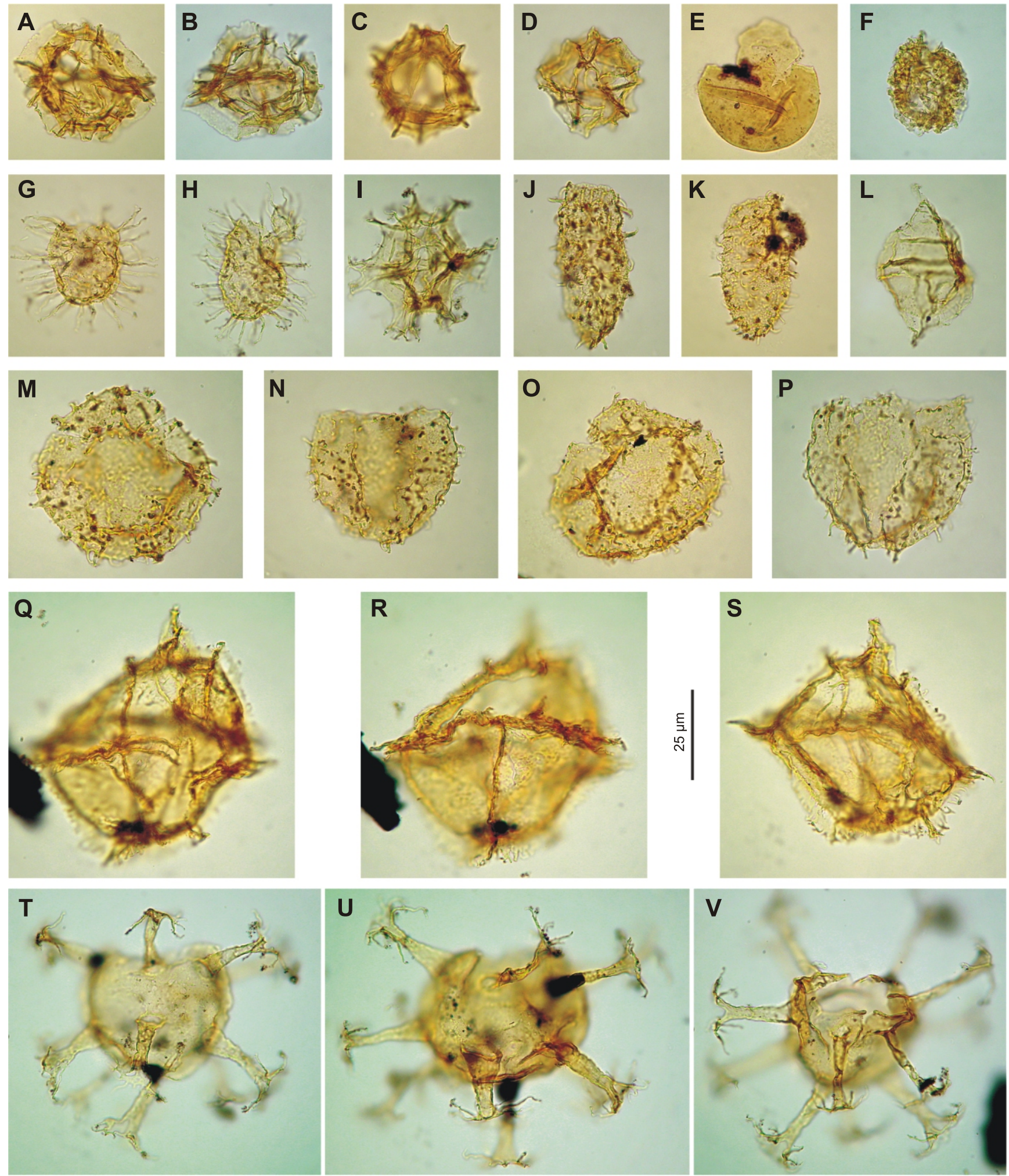

Fig. 7. Dinoflagellate cysts from the top of the Pieniny Limestone Formation at Szczawnica-Zabaniszcze (sample SzZ27)

A, B - Pterodinium premnos; C - Pterodinium cingulatum; D - Pterodinium sp.; E - Escharisphaeridia sp.; F - Chlamydophorella sp.; G - Tanyosphaeridium regulare; H - Tanyosphaeridium sp.; I - Spiniferites sp.; J, K - Prolixosphaeridium parvispinum; L - Subtilisphaera sp.; M-P - Cerbia tabulata; Q-S - Rhynchodiniopsis aptiana (Q, R: same specimen, various foci); T-V - Oligosphaeridium complex 

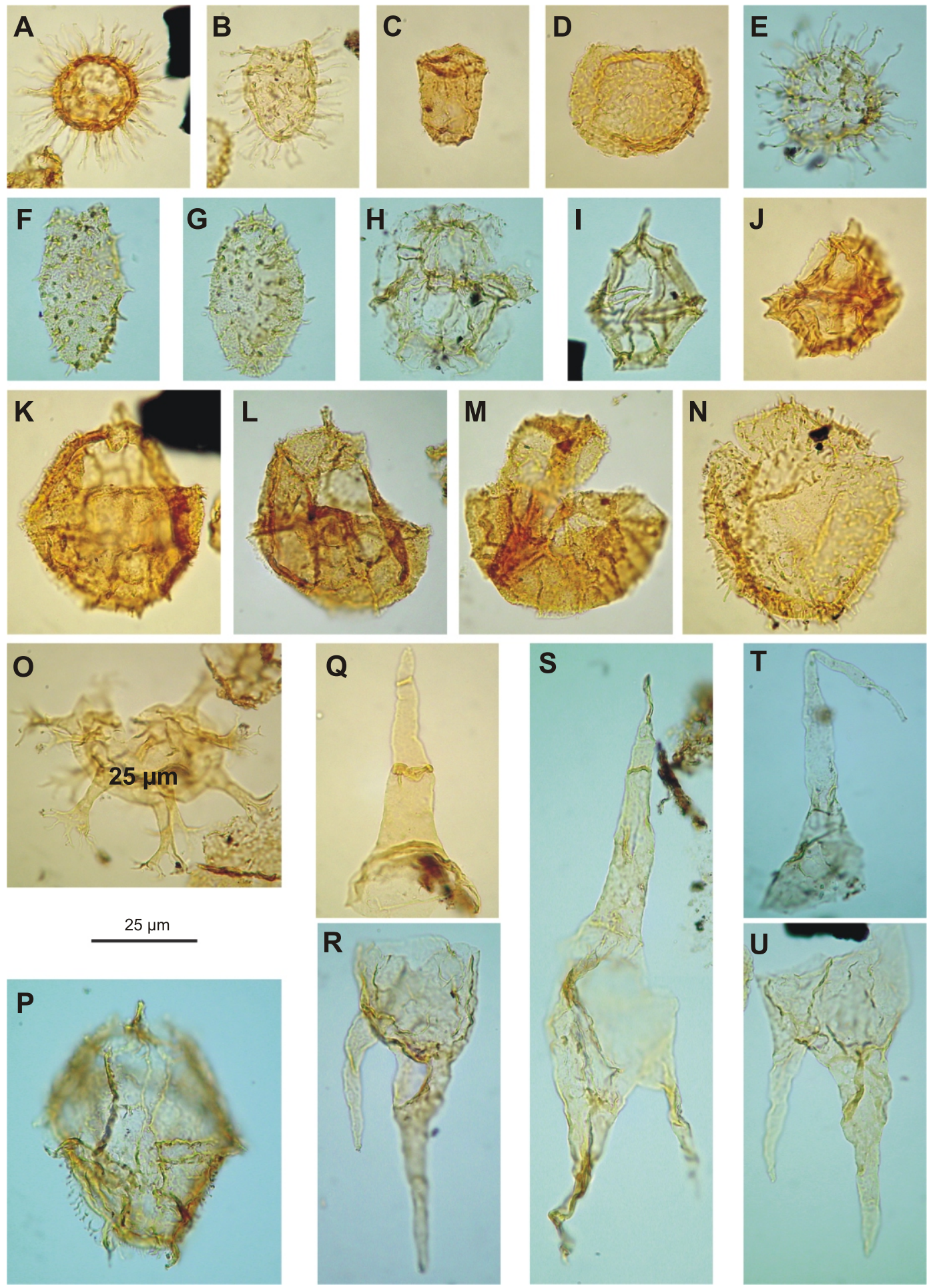

Fig. 8. Dinoflagellate cysts from the Kapuśnica Formation at Szczawnica-Zabaniszcze (sample SzZ28)

A - Dapsilidinium multispinosum; B - Tanyosphaeridium isocalamum; C - Druggidinium? sp.; D - Valensiella reticulata; E - Kiokansium sp.; F, G - Prolixosphaeridium parvispinum; H - Heslertonia heslertonensis; I - Gonyaulacysta? kleithria; J - Gonyaulacysta sp.; K-M - Tehamadinium sp.; N - Circulodinium distinctum; $\mathbf{O}$ - Oligosphaeridium complex; P - Rhynchodiniopsis aptiana; Q, R - Odontochitina operculata; S - Odontochitina imparilis; T, U - Odontochitina operculata 
sphaeridium ?phoenix). Both specimens are dark coloured and show traces of corrosion. Sample SzZ31 yielded a single, highly corroded specimen of Odontochitina operculata. Sample SzZ32 contains up to $10 \%$ of aquatic palynomorphs. Their assemblage consists of small sub-spherical forms, the majority of uncertain taxonomic affinities. Some of them represent Pterospermella and presumably Cyclopsiella-like forms. The other are dinoflagellate cysts questionably determined as Dinogymnium sp.; they are thin-walled, well-preserved and rather pale-coloured. This preservation contrasts with highly corroded specimens (e.g., Cerbia tabulata, Prolixosphaeridium parvispinum, Oligosphaeridium sp.), the maturity of which suggesting that they are reworked (Fig. 9). Sample SzZ34 contains moderately preserved, single specimens of Circulodinium and Oligosphaeridium complex.

The Opaleniec Formation. Samples collected from the further part of the exposure treated here as the Opaleniec Formation (calcareous spotted shale: SzZ35-44) yielded palynofacies characterized by a high ratio of sporomorphs (10-35\%) and dinoflagellate cysts (5-30\%); assemblages of the latter are generally taxonomically diverse, although slightly varying between different samples (Fig. 10). Sample SzZ35 contains dinoflagellate cysts dominated by Chytroeisphaeridium chytroides, Endoscrinium asymmetricum and Epiplosphaera specimens. Lithodinia and Ctenidodinium are frequent in sample SzZ37, whereas sample SzZ38 yielded dominant Nannoceratopsis pellucida. The latter species dominates in sample SzZ41, which as in sample SzZ38 contains palynofacies dominated by black opaque phytoclasts. A further three samples yielded gradual decrease in the palynomorph ratio, which reaches the lowest value (8-10\%) in samples SzZ43 and SzZ44. Dinoflagellate cyst assemblages from these samples show some taxonomic differences: the one from SzZ42 is relatively diverse, whereas the ones from the remaining two samples are impoverished, being dominated by Lithodinia specimens (Fig. 11).

The Szlachtowa Formation. Samples from the Szlachtowa Formation (SzZ45-52) contain a uniform palynofacies dominated by land-derived palynodebris. Dinoflagellate cysts are generally subordinate, although their ratio oscillates between $2-15 \%$ (except for sample SzZ49, which contains almost exclusively terrestrial palynodebris; Fig. 12). Dinoflagellate cysts from all samples of the Szlachtowa Formation are fairly well-preserved. Sample SzZ45 contains an assemblage (app. $20 \%$ of palynofacies) dominated by the genus Nannoceratopsis (various species: N. ?gracilis, $N$. spiculata, $N$. dictyambonis, $N$. raunsgaardii) and thin-walled specimens of Kallosphaeridium. A further sample SzZ46, collected from a large exposure, yielded palynofacies dominated by palynodebris; aquatic palynomorphs include dinoflagellate cysts (up to $5 \%$ ) and single specimens of foraminiferal organic linings and acritarchs. Dinoflagellate cysts are dominated by Nannoceratopsis gracilis; Dissiliodinium and Kallosphaeridium are subordinate. A following sample SzZ47 contains similar palynofacies but differs by a different composition of the dinoflagellate cyst assemblage, which contains a higher ratio of Dissiliodinium compared to less frequent Nannoceratopsis gracilis. Samples SzZ48 and SzZ50 (collected from just below a $20 \mathrm{~cm}$ thick sandstone layer, and $25 \mathrm{~cm}$ above it, respectively), in turn, contain assemblages (over $15 \%$ ) dominated by Nannoceratopsis (N. ambonis, $N$. gracilis, $N$. sp.) Dissiliodinium is represented by a few specimens only ( $D$. lichenoides, D. psilatum); rare Batiacasphaera and Kallosphaeridium occur. A completely different palynofacies was yielded by sample SzZ49 taken from a mudstone just above the $20 \mathrm{~cm}$ sandstone layer: it consists almost exclusively of terrestrial palynodebris; rare, highly dispersed dinoflagellate cysts are poorly preserved, but taxonomically their assemblage resembles that from the previous sample (it consists of Nannoceratopsis, Dissiliodinium, Kallosphaeridium and Batiacasphaera specimens). A higher sample SzZ51, collected from the NE part of the exposure, yielded palynofacies with infrequent dinoflagellate cysts $(2-3 \%)$. Their assemblage is similar to the ones from samples SzZ48 and SzZ50 by the presence of the same taxa, but differs by their different ratio Dissiliodinium lichenoides, D. psilatum and Kallosphaeridium $\mathrm{sp}$. are much more frequent than subordinate Nannoceratopsis ambonis and $N$. gracilis. The highest sample SzZ52 yielded, in turn, a much more frequent $(10 \%)$ assemblage with common Dissiliodinium and Kallosphaeridium specimens; it is distinguished by the occurrence of Dissiliodinium giganteum (Fig. 13).

\section{AGE INTERPRETATION}

The presence of dinoflagellate cysts in all samples studied allows their dating (Fig. 14). In most cases their interpretation is consistent within a particular lithostratigraphic unit.

The Pieniny Limestone Formation. A single sample collected from the topmost part of this lithostratigraphic unit at Szczawnica-Zabaniszcze (Fig. 5A) yielded a Late Barremian-earliest Aptian assemblage. This interpretation is based on the co-occurrence of Rhynchodiniopsis aptiana, and Cerbia tabulata. According to Stover et al. (1996) Cerbia tabulata appeared during the late Early Barremian-Aptian. Rhynchodiniopsis aptiana, in turn, has stratigraphical range in the Tethyan Realm limited to the latest Hauterivian-earliest Aptian (Torricelli, 2000). A similar age was inferred by E. Gedl (2007) for the uppermost part of the Pieniny Limestone Formation exposed at the bank of the Grajcarek Creek several tens of metres from this site.

The Kapuśnica Formation. Sample SzZ28 collected from the most basal part of the unit (Fig. 5A) contains Rhynchodiniopsis aptiana but lacks Cerbia tabulata. This may indicate an earliest Aptian age. The other species from this sample, such as Diphasosphaera stolidata, Heslertonia heslertonensis, Pterodinium premnos, Gonyaulacysta? kleithria, have their highest occurrences in the Lower Aptian (Duxbury, 1983). Samples SzZ30A and SzZ30B contain species non-diagnostic of age. The only noticeable feature is the frequent occurrence of Valensiella reticulata.

The Wronine Formation. Non-calcareous spotted shale exposed just above (in a stratigraphical sense) the Kapuśnica Formation (Fig. 14) yielded infrequent mid-Cretaceous dinoflagellate cysts such as Odontochitina operculata (Barremian-Early Maastrichtian; Stover et al., 1996). Precise dating of their assemblages is thus impossible. Cerbia tabulata from sample SzZ32 (as in sample SzZ30B) is likely reworked. E. Gedl (2007) described, from the Wronine Formation exposed at the bank of the Grajcarek Creek, various assemblages, characteristic of the Aptian and Albian, and suggesting either tectonic repetition of the section studied or reworking.

The Opaleniec Formation. This lithostratigraphic unit was distinguished in the section studied by the presence of taxonomically consistent Jurassic dinoflagellate cysts (samples SzZ35-44; Fig. 5D). Most of the species determined appeared for the first time in the Late Bajocian: all samples contain Ctenidodinium combazii, Endoscrinium asymmetricum and Chytroeisphaeridium chytroides; Nannoceratopsis pellucida was found in samples SzZ38-43 and Dichadogonyaulax 


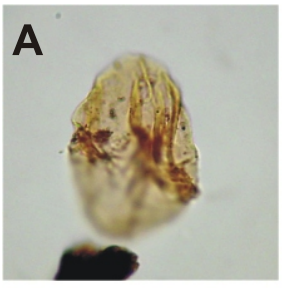

$\mathbf{F}$
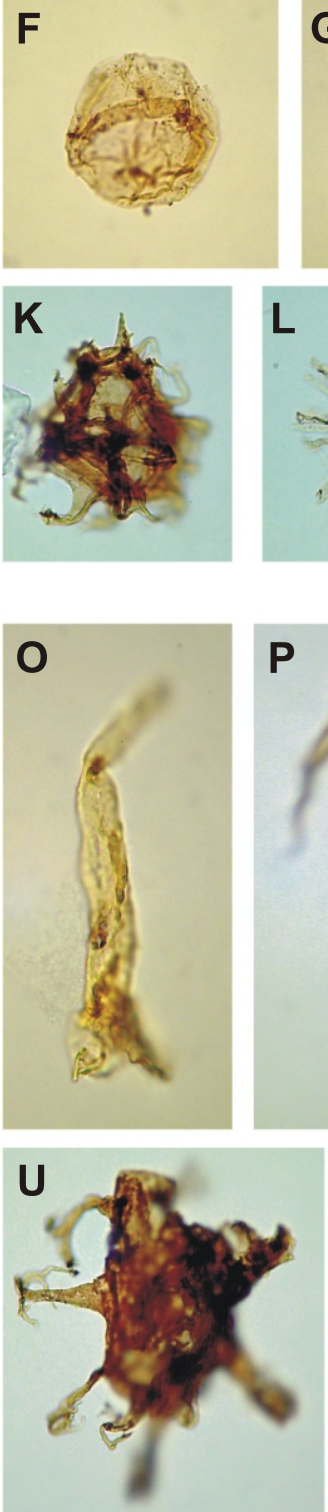
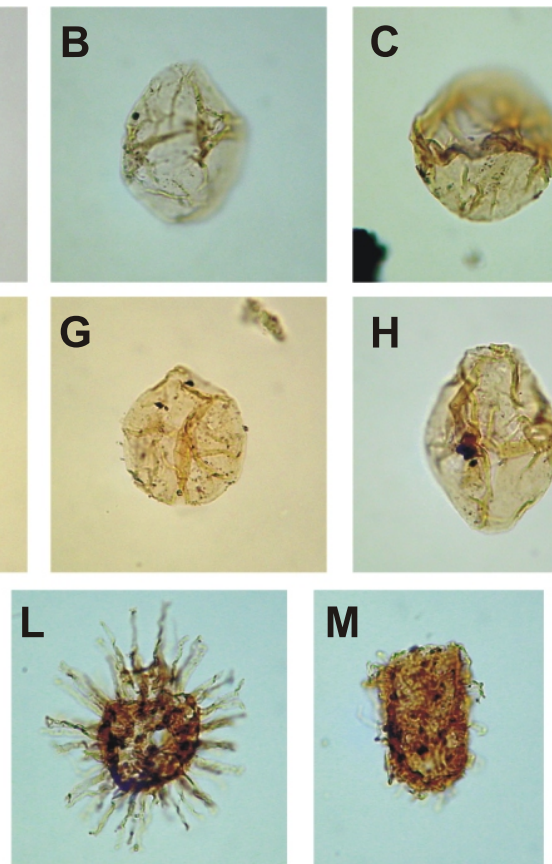

$25 \mu \mathrm{m}$

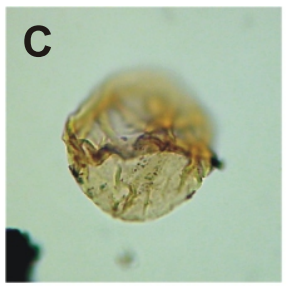

\section{H}

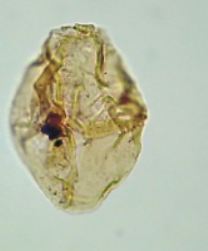

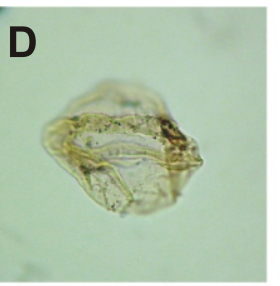

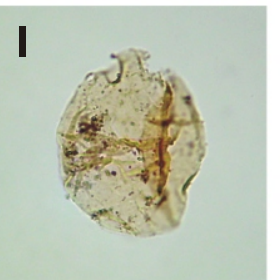

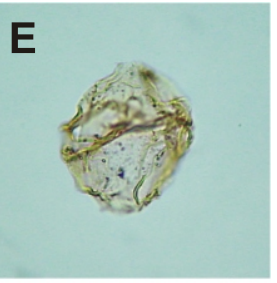
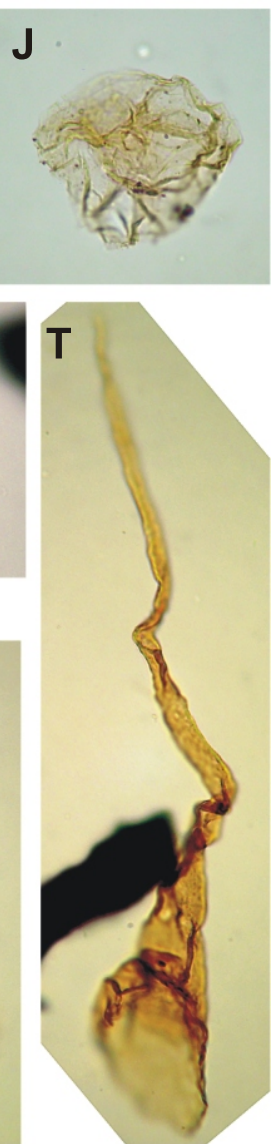
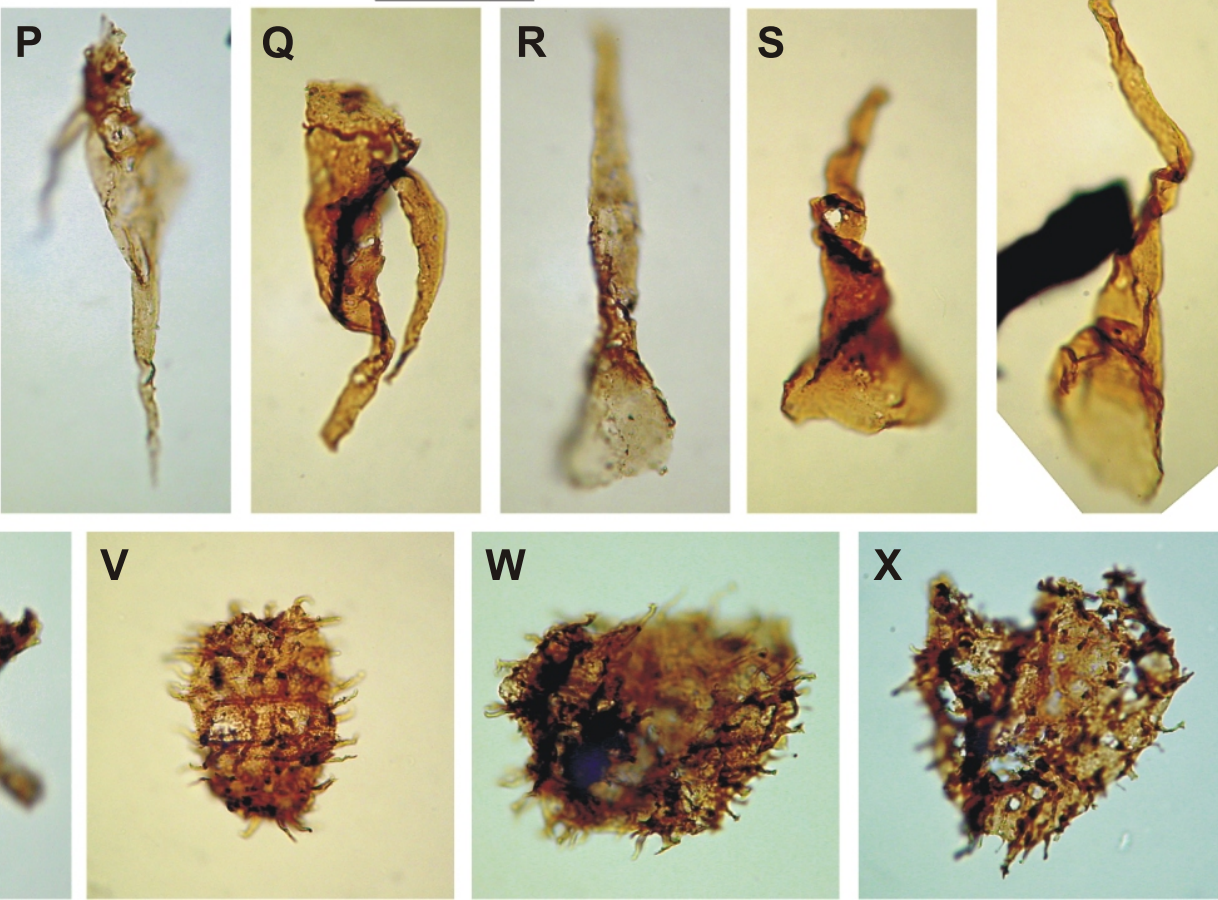

Fig. 9. Dinoflagellate cysts from the Wronine Formation at Szczawnica-Zabaniszcze (samples SzZ29: O; SzZ31: N; SzZ32: A-J, U-X; SzZ33: K-M, T)

A-J - Dinogymnium? sp.; K - Spiniferites sp.; L - Dapsilidinium warrenii; $\mathbf{M}$ - Tanyosphaeridium sp.; $\mathbf{N}-\mathbf{T}$ Odontochitina operculata; U - Oligosphaeridium sp.; V - Prolixosphaeridium parvispinum; W, X - Cerbia tabulata

sellwoodii occurs in two samples SzZ36 and SzZ37 (e.g., Feist-Burkhardt and Monteil, 1997; Bucefalo Palliani and Riding, 1997). However, the presence of a few species, namely Atopodinium prostatum, Sirmiodiniopsis orbis and Dingodinium minutum may indicate a younger, Bathonian age for the Opaleniec Formation studied (see e.g., Feist-Burkhardt and Wille, 1992). An even younger, Callovian, age may be suggested by the presence of the chorate species Systematophora penicillata and Surculosphaeridium? vestitum found in most samples. These species are known from Callovian and younger strata (e.g., Prauss, 1989; Feist-Burkhardt and Wille, 1992). Atopodinium sp. A (a morphological variety of Atopodinium) was illustrated by Feist-Burkhardt and Wille (1992: pl. 3.3) as an Early Callovian species.

The assemblage found during the present study in the Opaleniec Formation can be correlated with the youngest one distinguished among three assemblages from this lithostratigraphic unit in the Grajcarek Succession by the author 


\begin{tabular}{|c|c|c|c|c|c|c|c|c|c|c|c|}
\hline Lith & & & Or & $n$ & iec & 0 & 1a & atio & & & \\
\hline Taxon $\quad$ Sample & 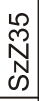 & $\begin{array}{l}0 \\
\tilde{N} \\
N \\
\omega\end{array}$ & $\begin{array}{l}\hat{N} \\
\mathbf{N} \\
\tilde{N}\end{array}$ & $\begin{array}{l}\infty \\
\tilde{N} \\
N \\
\omega\end{array}$ & 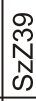 & \begin{tabular}{l}
$O$ \\
\multirow{N}{N}{} \\
n
\end{tabular} & $\begin{array}{l}- \\
\mathbf{J} \\
\mathcal{N}\end{array}$ & $\begin{array}{l}\mathcal{N} \\
\mathcal{N} \\
\mathcal{N}\end{array}$ & & & $\mid \begin{array}{l}\text { N } \\
N \\
N\end{array}$ \\
\hline Endoscrinium asymmetricum & c & $\mathrm{x}$ & $\mathrm{x}$ & $\mathrm{x}$ & $\mathrm{x}$ & $\mathrm{x}$ & $\mathrm{x}$ & $\mathrm{x}$ & $\mathrm{x}$ & & $\mathrm{x}$ \\
\hline Epiplosphaera spp. & c & $x$ & $\mathrm{x}$ & $\mathrm{x}$ & $\mathrm{x}$ & $\mathrm{x}$ & $\mathrm{x}$ & $\mathrm{x}$ & $\mathrm{x}$ & & $\mathrm{x}$ \\
\hline Chytroeisphaeridium chytroides & $\mathrm{c}$ & $\mathrm{x}$ & $\mathrm{x}$ & $\mathrm{x}$ & $\mathrm{x}$ & $\mathrm{x}$ & $\mathrm{x}$ & $\mathrm{x}$ & $\mathrm{x}$ & & $x$ \\
\hline Chytroeisphaeridium sp. & $\mathrm{x}$ & & & & & & & & & & \\
\hline Escharisphaeridia sp. & $\mathrm{x}$ & $x$ & $\mathrm{x}$ & & & & & & & & \\
\hline Surculosphaeridium? vestitum & $\mathrm{x}$ & $\mathrm{x}$ & $\mathrm{x}$ & & $\mathrm{x}$ & c & & $\mathrm{x}$ & $\mathrm{x}$ & & \\
\hline Systematophora penicillata & $\mathrm{x}$ & $x$ & $\mathrm{x}$ & & $\mathrm{x}$ & $\mathrm{x}$ & $\mathrm{x}$ & $\mathrm{x}$ & $\mathrm{x}$ & & \\
\hline Batiacasphaera spp. & $\mathrm{x}$ & $\mathrm{x}$ & $\mathrm{x}$ & $\mathrm{x}$ & $\mathrm{x}$ & & $\mathrm{x}$ & & & & \\
\hline Ctenidodinium combazii & $\mathrm{x}$ & $\mathrm{x}$ & $\mathrm{c}$ & $\mathrm{x}$ & c & $\mathrm{x}$ & $\mathrm{c}$ & $\mathrm{x}$ & $\mathrm{x}$ & & $x$ \\
\hline Ctenidodinium sp. & $x$ & & & & & & & & & & \\
\hline Polygonifera sp. & $x$ & $x$ & & & & $\mathrm{x}$ & & $\mathrm{x}$ & & & \\
\hline Endoscrinium sp. & $x$ & $x$ & $\mathrm{x}$ & & & & & $x$ & & & \\
\hline Tubotuberella eisenackii & $\mathrm{x}$ & & $\mathrm{x}$ & & & $\mathrm{x}$ & & & & & \\
\hline Epiplosphaera? sp. & $\mathrm{x}$ & & & & & & & & $\mathrm{x}$ & & \\
\hline Cleistosphaeridium iaculigerum & $x$ & & & & $x$ & & $x$ & $x$ & & & \\
\hline Sentusidinium spp. & $\mathrm{x}$ & $x$ & $x$ & & $x$ & & $x$ & $x$ & $x$ & & \\
\hline Lithodinia jurassica & & $\mathrm{x}$ & $\mathrm{x}$ & & & & & & & & \\
\hline Lithodinia caytonensis & & $x$ & c & $\mathrm{x}$ & c & c & & c & c & & c \\
\hline Atopodinium sp. A & & $x$ & $\mathrm{x}$ & $\mathrm{x}$ & $\mathrm{x}$ & $x$ & & $\mathrm{x}$ & & & \\
\hline Chytroeisphaeridium cerastas & & $\mathrm{x}$ & $\mathrm{x}$ & & & & & & & & \\
\hline Cribroperidinium sp. & & $x$ & & & & & & & & & \\
\hline Dichadogonyaulax sellwoodii & & $\mathrm{x}$ & $\mathrm{x}$ & & & & & & & & \\
\hline Batiacasphaera? sp. & & $x$ & & $\mathrm{x}$ & & & & & & & \\
\hline Gonyaulacysta jurassica adecta & & $x$ & & & & & & & & & \\
\hline Pareodinia sp. & & $\mathrm{x}$ & & & & & & & & & \\
\hline Chlamydophorella sp. & & $x$ & $x$ & $x$ & & & & & & & \\
\hline Dingodinium minutum & & $x$ & $x$ & & $\mathrm{x}$ & & & $x$ & & & \\
\hline Kallosphaeridium? sp. & & $x$ & & & $\mathrm{x}$ & & & & $x$ & & \\
\hline Tubotuberella dangeardi & & $x$ & & & & & & & & & \\
\hline Tubotuberella apatela & & $\mathrm{x}$ & & & & & & & & & \\
\hline Gonyaulacysta jurassica & & $x$ & $\mathrm{x}$ & $\mathrm{x}$ & & & & & & & \\
\hline Tubotuberella egemeni & & $x$ & & & & & & & & & \\
\hline Systematophora ?orbifera & & $x$ & $\mathrm{x}$ & & & & & $x$ & $x$ & & \\
\hline Sirmiodiniopsis orbis & & $x$ & $x$ & & $x$ & & & & & & \\
\hline Atopodinium prostatum & & & $\mathrm{x}$ & & & & & & & & \\
\hline Nannoceratopsis pellucida & & & & $\mathrm{a}$ & $\mathrm{x}$ & $x$ & $a$ & $x$ & $x$ & & \\
\hline Leptodinium mirabile & & & & $x$ & $x$ & & & & & & \\
\hline Wanaea sp. & & & & & $x$ & & & & & & \\
\hline Ctenidodinium continuum & & & & & & $x$ & & & & & \\
\hline Gonyaulacysta pectinigera & & & & & & & $\mathrm{x}$ & & & & \\
\hline Leptodinium sp. & & & & & & & $\mathrm{x}$ & & & & \\
\hline Apteodinium sp. & & & & & & & & $\mathrm{x}$ & & & \\
\hline
\end{tabular}

Fig. 10. Dinoflagellate cyst distribution in the Opaleniec Formation at Szczawnica-Zabaniszcze

Explanations as in Figure 6
(Gedl, 2008d). An Upper Bathonian assemblage with infrequent Ctenidodinium combazii, and Atopodinium polygonale and Dingodinium minutum was found in the upper part of the Opaleniec Formation at Sztolnia, Krupianka and Hulina Mt. Atopodinium sp. A (as A. prostatum) was found at Sztolnia (Szt28). However, it cannot be excluded that these assemblages are Callovian, because as with the one from this study, they contain chorate species of Systematophora and Surculosphaeridium (due to poor preservation determined by Gedl, 2008d to generic level only).

The Szlachtowa Formation. All eight samples from this lithostratigraphic unit contain dinoflagellate cysts. Their age-interpretation confirms observations from the exposure suggesting normal attitude of the strata (they dip at an angle of $40-50^{\circ}$ north-west), which means that the oldest part of the Szlachtowa Formation is exposed in the northwestern part (sample SzZ45), getting younger to the south-east (Fig. 5D).

The assemblage from sample SzZ45 contains species which commonly appeared during the latest Toarcian through the earliest Bajocian: Moesiodinium raileanui, Nannoceratopsis ambonis, Nannoceratopsis dictyambonis, Nannoceratopsis raunsgaardii, Phallocysta elongata. But there are no species that appeared during the Middle-Late Aalenian (e.g., Dissiliodinium spp., Carpathodinium sp. A), which occur in stratigraphically younger part of the exposure. Another stratigraphically important taxon is Hyalosphaera? sp. found in SzZ45 only. Hyalosphaera ephemera is known from the Upper Toarcian-Lower Aalenian (levesquei-opalinum; Prauss, 1989). Therefore, an Aalenian, presumably an Early Aalenian age can be suggested for northernmost part of the Szlachtowa Formation (Fig. 14). However, an older, latest Toarcian age cannot be excluded since the assemblage from sample SzZ45 lacks Nannoceratopsis evae, a species known from the Aalenian-Bajocian. On the other hand, this species is relatively rare in other outcrops of the Szlachtowa Formation (Gedl, $2008 d$ ), and in the present material only a single specimen was found in a younger sample SzZ52. An Early Toarcian age for this sample might be also supported by the presence of Valvaeodinium cf. koessianum. This was described by the author from the Szlachtowa Formation at Krzonowe (sample KrzS1) and interpreted as latest Toarcian-Aalenian (Gedl, 2008d). Wille and Gocht (1979) described similar morphotypes from the Pliensbachian-Lower Toarcian of SW Germany.

The higher part of the Szlachtowa Formation, which forms continuous outcrop (samples SzZ46-51; Fig. 14) yielded assemblages, which might be interpreted as Middle-Late Aalenian. This interpretation is based on the presence of frequent Dissiliodinium specimens (mainly $D$. lichenoides), and absence of typical Early Bajocian (Dissiliodinium giganteum) or younger taxa (e.g., Ctenidodinium spp.) known from younger parts of the Szlachtowa Formation (e.g., Gedl, 2008d).

Dissiliodinium giganteum has its lowest occurrence in the section studied in the highest sample SzZ52 (Fig. 14). This species, known to have appeared for the first time during the earliest Bajocian (e.g., Feist-Burkhardt, 1990; Feist-Burkhardt and Monteil, 2001), is widespread in the middle part of the Szlachtowa Formation of the Pieniny Klippen Belt in Poland (Gedl, 2008d; Barski et al., 2012). Its presence in the topmost part of the exposure studied points to a lowermost Bajocian age.

The dinoflagellate cyst assemblages described above, and their age-interpretation, allow correlation with previously described assemblages from other exposures of the Szlachtowa Formation in the Pieniny Klippen Belt. The oldest assemblage from sample SzZ45 can be correlated with the Phallocysta elongata Dinoflagellate Cyst Zone of Gedl (2008d) found in the 

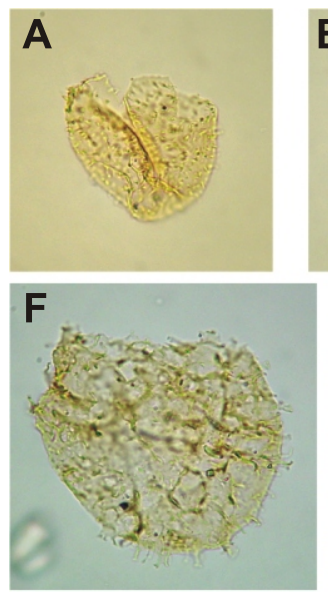

$J$
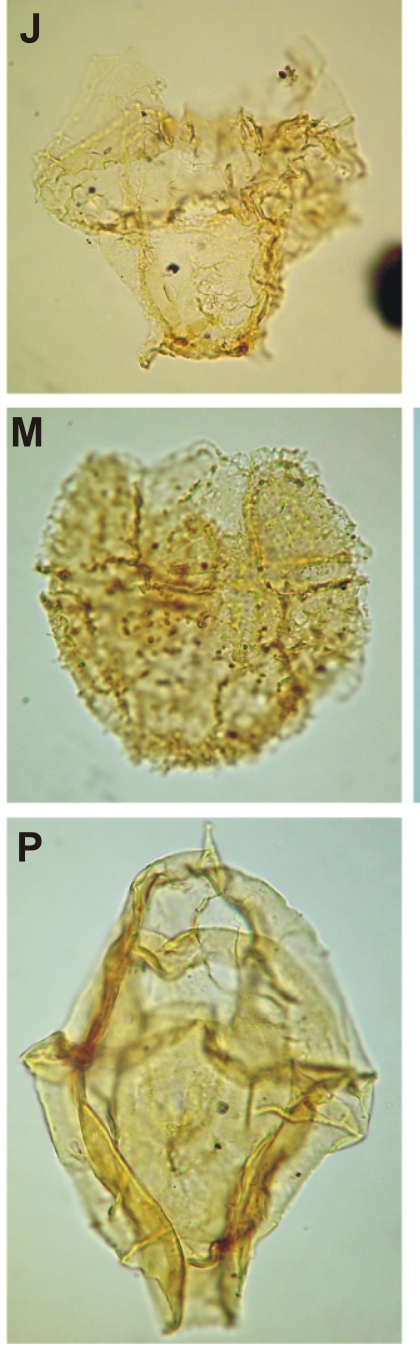
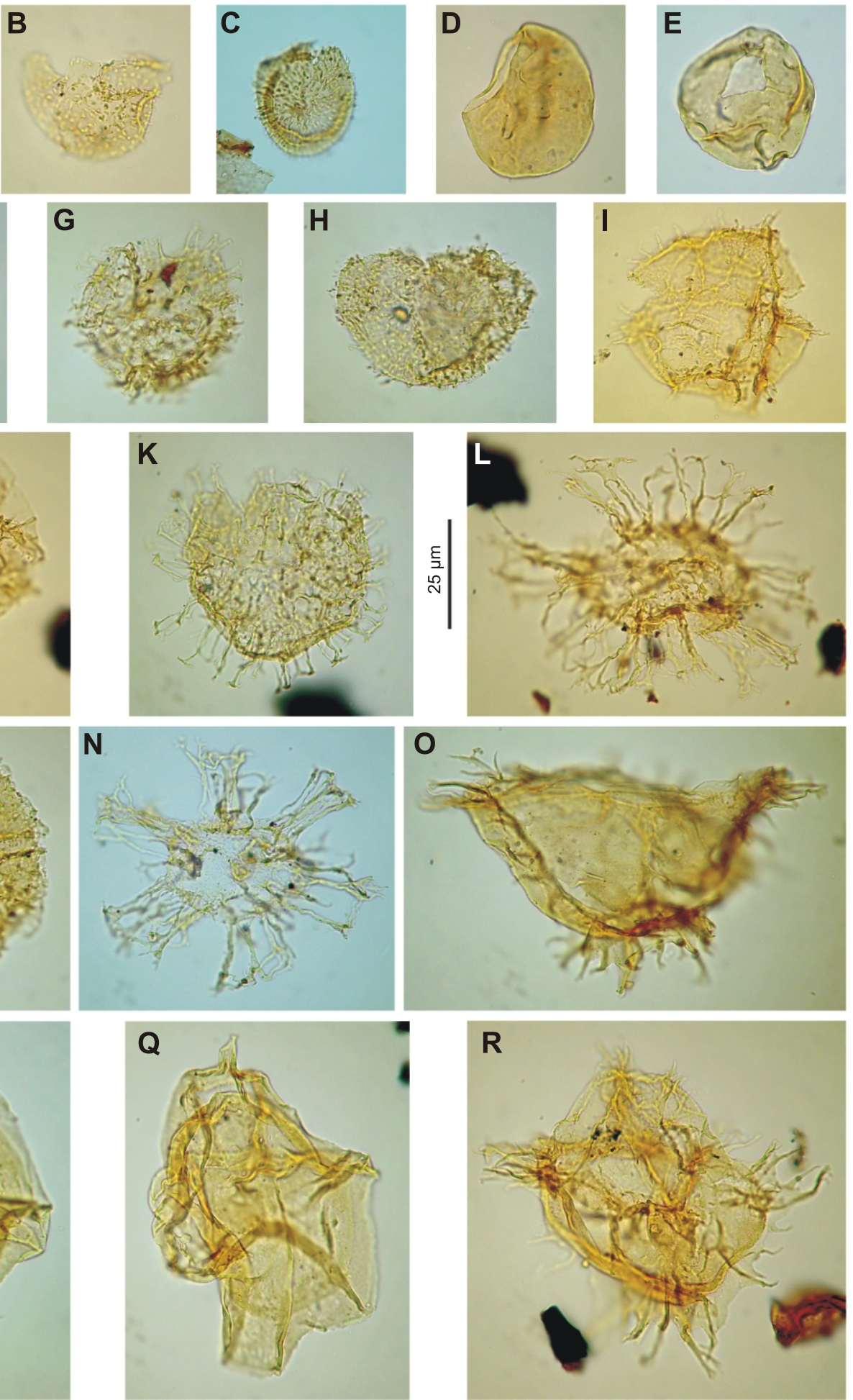

Fig. 11. Dinoflagellate cysts from the Opaleniec Formation at Szczawnica-Zabaniszcze (SzZ36: A-K, M, O, P; SzZ37: L, N, Q, R)

A-C - Sentusidinium spp.; D, E - Chytroeisphaeridium chytroeides; F, G - Epiplosphaera spp.; H - Sentusidinium sp.; I - Dichadogonyaulax sellwoodii; J - Atopodinium prostatum; K - Surculosphaeridium? vestitum; L - Systematophora penicillata; $\mathbf{M}$ - Lithodinia caytonensis; $\mathbf{N}$ - Systematophora ?orbifera; $\mathbf{O}$ - Ctenidodinium combazii; $\mathbf{P}$ - Endoscrinium Iuridum; $\mathbf{Q}$ - Endoscrinium asymmetricum; $\mathbf{R}$ - Ctenidodinium combazii 


\begin{tabular}{|c|c|c|c|c|c|c|c|c|}
\hline Lithostratigraphy & \multicolumn{8}{|c|}{ Szlachtowa Formation } \\
\hline Taxon - Sample & 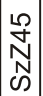 & $\begin{array}{l}0 \\
N \\
N\end{array}$ & $\begin{array}{l}\mathcal{N} \\
\text { N } \\
\omega\end{array}$ & $\mid \begin{array}{l}\infty \\
\stackrel{N}{N} \\
\infty\end{array}$ & $\begin{array}{l}\stackrel{9}{\mathrm{~N}} \\
\text { N }\end{array}$ & 怘 & 5 & \\
\hline Batiacasphaera spp. & $\mathrm{x}$ & $\mathrm{x}$ & & $\mathrm{x}$ & $\mathrm{x}$ & $\mathrm{x}$ & $\mathrm{x}$ & $\mathrm{x}$ \\
\hline Moesiodinium raileanui & $\mathrm{x}$ & & & & & & $\mathrm{x}$ & $\mathrm{x}$ \\
\hline Kallosphaeridium? sp. & $\mathrm{x}$ & & & & & & & \\
\hline Nannoceratopsis ambonis & $\mathrm{a}$ & & & $\mathrm{x}$ & & $\mathrm{c}$ & & $\mathrm{x}$ \\
\hline Nannoceratopsis spiculata & $x$ & & & & & & & \\
\hline Kallosphaeridium praussii & c & $x$ & $\mathrm{x}$ & $\mathrm{x}$ & & $x$ & & $\mathrm{x}$ \\
\hline Kalyptea stegasta & $\mathrm{x}$ & & & & & & & \\
\hline Hyalosphaera? sp. & $\mathrm{x}$ & & & & & & & \\
\hline Nannoceratopsis raunsgaardii & $\mathrm{x}$ & & & & & & & \\
\hline Kallosphaeridium spp. & $x$ & $\mathrm{x}$ & $\mathrm{x}$ & $\mathrm{x}$ & & & $x$ & $\mathrm{x}$ \\
\hline Nannoceratopsis dictyambonis & $\mathrm{x}$ & & & & & $\mathrm{x}$ & & \\
\hline Phallocysta elongata & $\mathrm{x}$ & $\mathrm{x}$ & $\mathrm{x}$ & & & $\mathrm{x}$ & & \\
\hline Pareodinia sp. & $x$ & & & & & & & \\
\hline Nannoceratopsis sp. & $\mathrm{x}$ & $\mathrm{x}$ & $\mathrm{x}$ & $\mathrm{x}$ & & $\mathrm{x}$ & $\mathrm{x}$ & \\
\hline Valvaeodinium cf. koessianum & $\mathrm{x}$ & & & & & & $?$ & \\
\hline Nannoceratopsis gracilis & $\mathrm{x}$ & a & c & $a$ & $\mathrm{x}$ & c & $\mathrm{x}$ & $\mathrm{x}$ \\
\hline Nannoceratopsis sp. A & $\mathrm{x}$ & $\mathrm{x}$ & $\mathrm{x}$ & $\mathrm{x}$ & & $\mathrm{x}$ & $\mathrm{x}$ & \\
\hline Escharisphaeridia sp. & $\mathrm{x}$ & & & $\mathrm{x}$ & $\mathrm{x}$ & & $\mathrm{x}$ & \\
\hline Dodekovia? sp. & $\mathrm{x}$ & $\mathrm{x}$ & & & & & & \\
\hline Valvaeodinium? sp. & $\mathrm{x}$ & & & & & & & \\
\hline Mendicodinium spp. & $\mathrm{x}$ & & $\mathrm{x}$ & & & & & \\
\hline Korystocysta sp. & $\mathrm{x}$ & & & & & & & \\
\hline Nannoceratopsis senex & $\mathrm{x}$ & $\mathrm{x}$ & & & & $\mathrm{x}$ & & \\
\hline Dissiliodinium lichenoides & & c & $\mathrm{c}$ & $\mathrm{x}$ & $\mathrm{x}$ & $\mathrm{x}$ & $\mathrm{x}$ & $\mathrm{x}$ \\
\hline Dissiliodinium psilatum & & c & $\mathrm{x}$ & $\mathrm{x}$ & & $\mathrm{x}$ & $\mathrm{x}$ & \\
\hline Dissiliodinium spp. & & $\mathrm{x}$ & $\mathrm{x}$ & $\mathrm{x}$ & & $\mathrm{x}$ & $x$ & c \\
\hline Dissiliodinium giganteum & & & & & & & & $x$ \\
\hline Valveodinium armatum & & & & & & & & $\mathrm{x}$ \\
\hline Carpathodinium sp. A & & & & & & & & $\mathrm{x}$ \\
\hline Nannoceratopsis evae & & & & & & & & $\mathrm{x}$ \\
\hline Gonyaulacysta? sp. & & & & & & & & $\mathrm{x}$ \\
\hline
\end{tabular}

Fig. 12. Dinoflagellate cyst distribution in the Szlachtowa Formation at Szczawnica-Zabaniszcze

? - questionable occurrence; other explanations as in Figure 6

Szlachtowa Formation at Krzonowe (sample KrzS1). Younger samples with Dissiliodinium spp. (SzZ46-51) can be correlated with the Upper Aalenian Dissiliodinium lichenoides Dinoflagellate Cyst Zone of Gedl (2008d), which has been distinguished in the Szlachtowa Formation exposed at Krzonowe (sample KrzS2), Szczawnica-Zabaniszcze (exposure at the Grajcarek bank; sample SzRz6), and Podubocze (Branisko Succession). The topmost part of the exposure studied, in turn, can be correlated with the Lower Bajocian Dissiliodinium giganteum Dinoflagellate Cyst Zone of Gedl (2008d). This zone has been distinguished at several sites within the Szlachtowa Formation of the Grajcarek and Branisko successions: Krupianka, Sztolnia, Hałuszowa, Potok Kręty, Podubocze I and Podubocze II (Gedl, 2008d).

\section{DISCUSSION}

The data presented in this paper undoubtedly show a Jurassic age for the Szlachtowa Formation. They agree well with results of previous micro- and macrofossil studies from this unit in Polish (e.g., Gąsiorowski, 1962; Birkenmajer and Pazdro, 1963, 1968; Błaszyk, 1968; Birkenmajer et al., 1970; Pugaczewska, 1971; Birkenmajer and Myczyński, 1977; Pazdro, 1979; Głuchowski et al., 1983; Głuchowski, 1987; Dudziak, 1986; Krawczyk et al., 1992; Birkenmajer and Tyszka, 1996; Birkenmajer and Gedl, 2004, 2007; Gedl, 2007, 2008d; Barski et al., 2012) and Slovak (Barski et al., 2012) sectors of the Pieniny Klippen Belt. In the light of these data, the rened suggestions of a Cretaceous age for the Szlachtowa Formation by Oszczypko et al. (2012) is untenable (see also Oszczypko et al., 2004; Birkenmajer et al., 2008; Gedl, 2008a, b, c; Oszczypko et al., 2008). Below, a critical discussion of their thesis is presented.

Oszczypko et al. (2012) suggest that the Szlachtowa Formation (the so-called "black flysch") and the Opaleniec Formation are of Cretaceous age because they are in contact in some outcrops with Cretaceous, mainly Upper Cretaceous units (see also Ksiażkiewicz, 1972). This phenomenon, however, cannot serve as a direct age-indicator in such a tectonically complicated structure as is the Pieniny Klippen Belt, especially given that some outcrops of the Szlachtowa and Opaleniec formations occur in contact with Jurassic units (e.g., Podubocze, Krupianka Creek; see e.g., Birkenmajer, 1979: p. 206, fig. 99B; Gedl, 2008d). To support the thesis of a Cretaceous age for the deposits in question, Oszczypko et al. (2012) present partly new, partly restudied microfaunal data, which in their opinion support this theory. In my opinion, however, their interpretation is erroneous, being based on material that does not represent the Szlachtowa and Opaleniec formations, or that is commonly contaminated.

Oszczypko et al. (2012: p. 424) conclude a Cretaceous age for these units on the basis of taxonomically impoverished foraminifera assemblages of a few samples only (most of their 71 samples studied appeared to be barren or to contain forms non-diagnostic of age), which frequently show features of contamination. Moreover, the samples which yielded these assemblages are usually collected from atypical lithofacies (e.g., red shale, radiolarite) or from deposits of uncertain superposition, usually from tectonic contacts or highly tectonized sections. Three samples which, according to Oszczypko et al. (2012), represent the Szlachtowa Formation exposed at Szczawnica-Zabaniszcze, were taken from contact intervals with the Wronine Formation (samples WP489, 9/10) and the Malinowa Shale Formation (sample WP490/490a; Oszczypko et al., 2012: fig. 4C, D). In fact, a contact between the Wronine Formation and the Szlachtowa Formation does not exist at the site studied. The Wronine Formation is in contact with the lithologically very similar Opaleniec Formation; passage of the latter to the Szlachtowa Formation is not exposed at all (Fig. 5D). Therefore, it may be suggested that the "productive" sample WP490/490a was collected from the Cretaceous Wronine Formation, but not from the Szlachtowa Formation, despite its wide extent in this outcrop (Fig. 5D). 

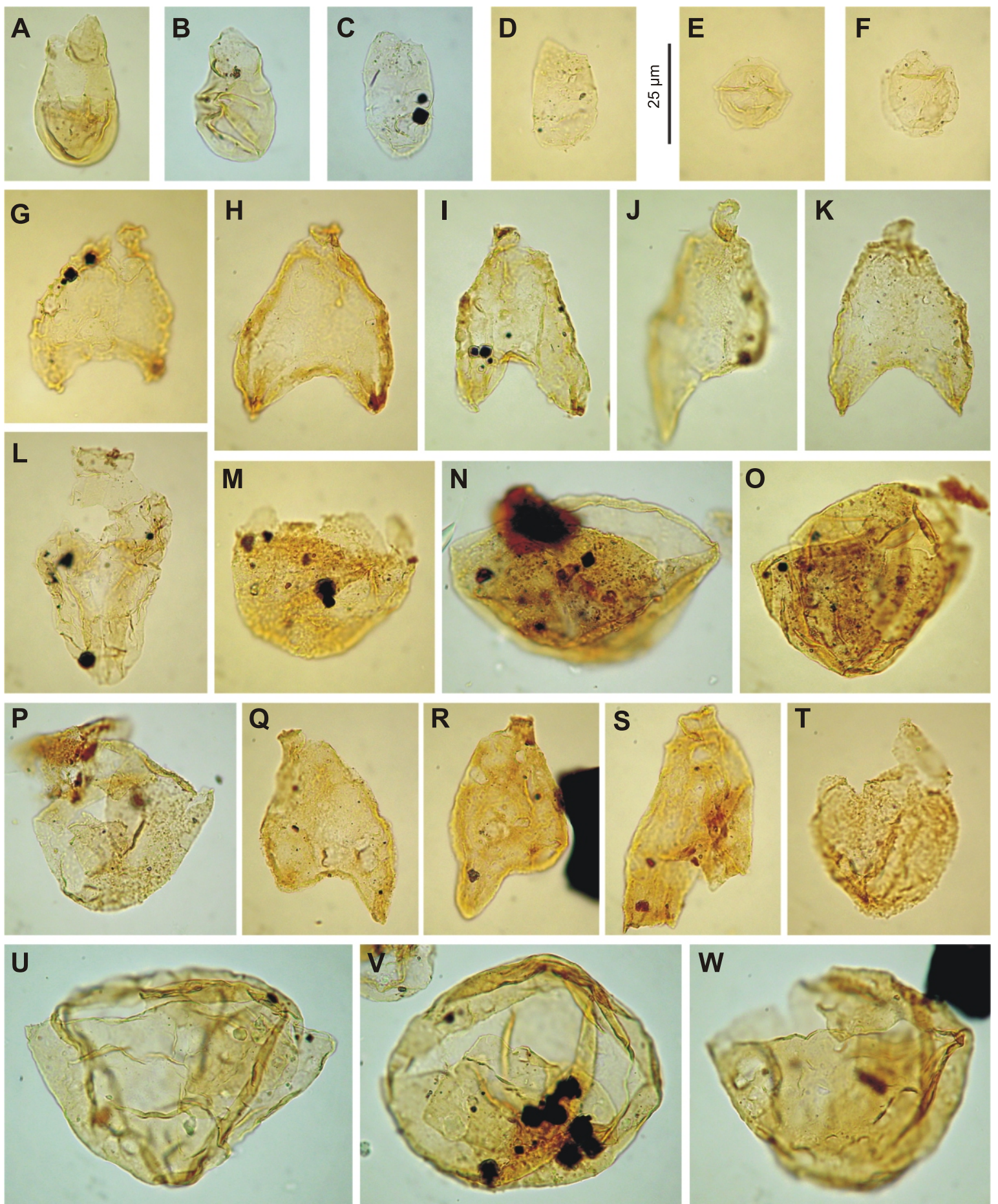

Fig. 13. Dinoflagellate cysts from the Szlachtowa Formation at Szczawnica-Zabaniszcze (SzZ45: A-M; SzZ47: N-P; SzZ48: Q-T; SzZ52: U-W)

A, B - Phallocysta elongata; C, D - Valvaeodinium cf. koessianum; E, F - Moesiodinium raileanui; G - Nannoceratopsis dictyambonis; H - Nannoceratopsis ambonis; I, J - Nannoceratopsis gracilis; K - Nannoceratopsis spiculata; L - Kallosphaeridium praussii; $\mathbf{M}$ - Batiacasphaera sp.; N-P - Dissiliodinium lichenoides; $\mathbf{Q}, \mathbf{R}$ - Nannoceratopsis gracilis; $\mathbf{S}$ - Nannoceratopsis sp.; $\mathbf{T}$ - Kallosphaeridium sp.; U-W - Dissiliodinium giganteum 


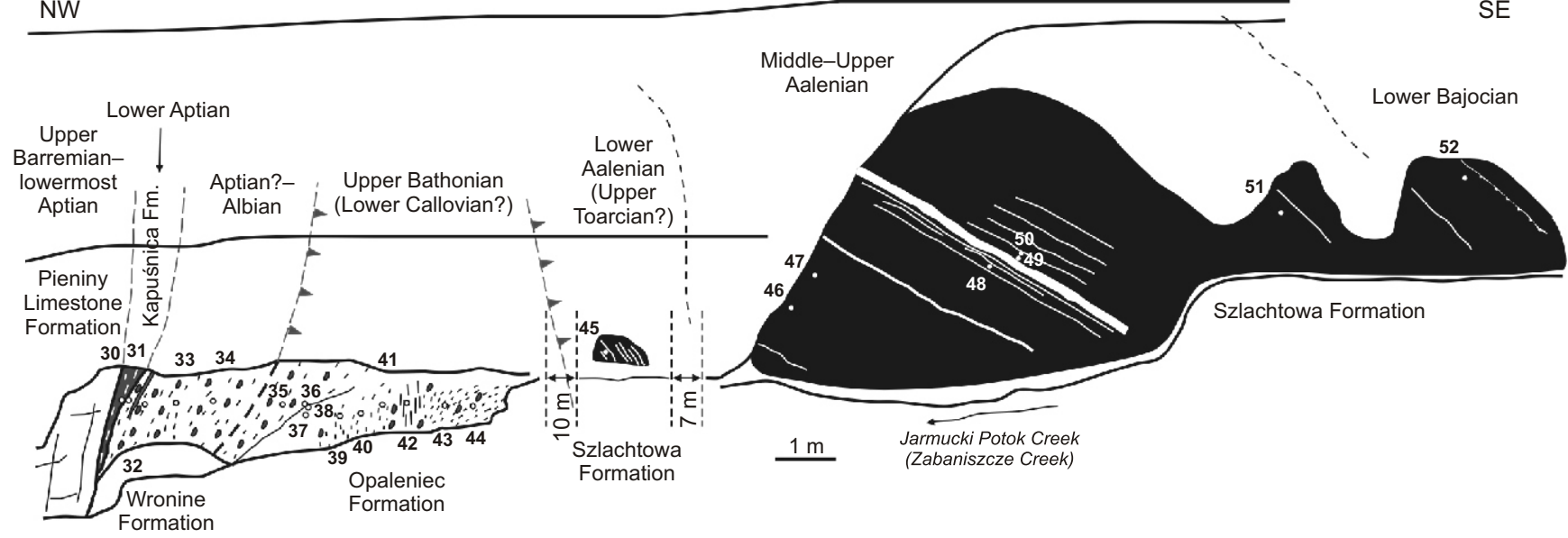

Fig. 14. Age interpretation of the strata of the Grajcarek Succession exposed at Szczawnica-Zabaniszcze

Similarly, an erroneous sampling procedure can be suggested for three samples with Cretaceous foraminifera collected from the southernmost part of exposure known as the "small waterfall" (Sztolnia A; 3/06 and 16/06: Opaleniec Formation, and 17/06: Szlachtowa Formation according to Oszczypko et al., 2012). This part of exposure shows a complicated, poorly exposed structure: the Szlachtowa Formation contacts to the south with: the Cretaceous Hulina Formation (according to Gedl, 2008a: fig. 2B1; see also Birkenmajer and Gedl, 2004: fig. 4; Birkenmajer et al., 2008: fig. 5A), the Cretaceous Malinowa Shale Formation and Jaworki Marl Formation (according to Oszczypko et al., 2004: fig. 7) or the Opaleniec Formation (according to Oszczypko et al., 2012: fig. 5).

Among samples with Cretaceous foraminifera from exposures along the Grajcarek Creek, and attributed by Oszczypko et al. (2012) to the Szlachtowa Formation: samples WP357/2-3 are dark grey shales with red intercalations (Grajcarek-Szlachtowa), sample WP370 is red shale, and sample WP943 is spotted limestone (both samples from the junction of the Sielski Creek with the Grajcarek Creek; Oszczypko et al. (2012: p. 432, fig. 2). Neither red shale nor spotted limestone are typical Szlachtowa Formation lithofacies (Birkenmajer, 1977: p. 27). Although Krawczyk and Słomka (1986, p. 55, fig. 11) noted a red shale occurrence in one section of the Szlachtowa Formation, where this lithology appears as small lenses (up to several centimetres long) and thin laminas within a $85 \mathrm{~cm}$ thick black shale layer, but they suggested that this exceptional lithology may be a result of siderite alteration (Krawczyk and Słomka, 1986: p. 100). It is symptomatic that of eight samples collected by Oszczypko et al. (2012) from Grajcarek Creek exposures and attributed to the Szlachtowa Formation, seven are either dark shale with intercalations of red shale (WP357) or green radiolarite with intercalations of red shale overlain by spotted limestone (samples WP370-375 and WP943; Oszczypko et al., 2012, p. 424), despite the Szlachtowa Formation in this area being well exposed and including easily accessible exposures that show typical developments of this lithostratigraphic unit.

Contamination is one of the explanations of the different age-interpretations of the Szlachtowa and Opaleniec formations. Birkenmajer and Pazdro (1968) suggested that Cretaceous foraminifera described by Sikora (1962) in the Szlachtowa Formation exposures from the upper course of the Sztolnia Creek (sections: Sztolnia A and Sztolnia B sensu Oszczypko et al., 2012) were a result of contamination (they found dark-coloured agglutinated forms in fresh rock, whereas
Late Cretaceous pale-coloured planktonic foraminifera appeared in the washed residuum; the latter were interpreted as washed-out from the Upper Cretaceous Malinowa Shale Formation; see also Birkenmajer, 1977: p. 25-27). Such an explanation was rejected by Oszczypko et al. (2004, 2008, 2012). However, Oszczypko et al. (2012) are not consistent in this matter in the case of their own material: Albian-Turonian Plectorecurvoides alternans in a "Lower Cretaceous" section of the Szlachtowa Formation is regarded by Oszczypko et al. (2012: p. 434) as "... specific contamination due to tectonic or other phenomena...". The authors do not explain what they understand by "other phenomena". In some samples treated by Oszczypko et al. (2012) as collected from the Szlachtowa and Opaleniec formations in the upper course of the Sztolnia Creek, they found very rare Early Cretaceous agglutinated, poorly preserved foraminifera (treated as age-diagnostic), associated with Late Cretaceous planktonic species of different colouration. An even more pronounced example of contamination in the material discussed is the occurrence of Paleogene foraminifera reported from the "Opaleniec Formation" in the upper course of the Sztolnia Creek.

An outstanding feature of Blaicher's (1973) foraminifera assemblages mentioned by Oszczypko et al. (2012) is the common mixture of specimens of various ages as in the case of the "Opaleniec" Formation samples from Sztolnia A section, which consist of mixed Jurassic, Early-Late Cretaceous and Paleogene species (Oszczypko et al., 2012: p. 433). Such material has limited value for stratigraphical evaluation. Foraminifera assemblages described by Blaicher (1973) show a characteristic dualism: the ones from the Sztolnia Beds (i.e. the Szlachtowa Formation) are commonly impoverished and poorly preserved, and samples are frequently barren; this contrasts with rich and better preserved assemblages from the Wronine and Hulina formations - a similar pattern characterizes the results of Oszczypko et al. (2012) who reported barren samples from the Szlachtowa Formation, whereas foraminifera have been found in samples from tectonic contacts with the former Cretaceous lithostratigraphic units, or in deposits which, in my opinion, do not represent the deposits in question.

Providing another argument for a Cretaceous age for the Szlachtowa Formation Oszczypko et al. (2012: p. 413) refer to the interpretation of Plašienka et al. (2012: p. 30, fig. 8) who questionably correlated the Szlachtowa Formation from the Jar-1 borehole (Jarabina vicinity, Slovakia) with Albian age. But Oszczypko et al. (2012) do not say that this correlation was not 


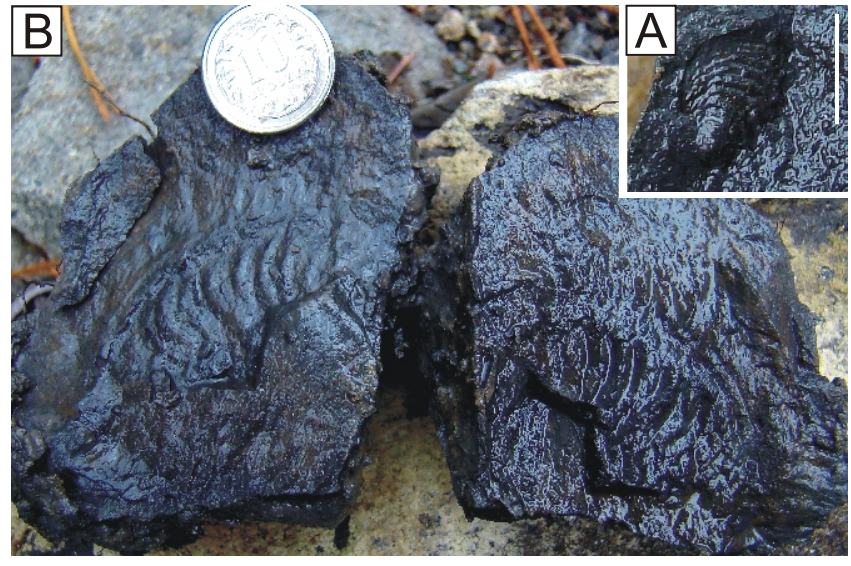

Fig. 15A - Bivalve Bositra buchi (scale bar = $4 \mathrm{~mm}$ ); B Aalenian ammonite Brasilia (Brasilia) sp. (B; coin diameter = $16.5 \mathrm{~mm})$ from the Szlachtowa Formation exposed near Jarabina (Slovakia; found by Š. Józsa and D. Plašienka, respectively, during fieldwork in Autumn 2012)

supported by micropalaeontological data. In fact, the Szlachtowa Formation from this borehole contains exclusively Jurassic dinoflagellate cysts (Aalenian-Early Bathonian). Moreover, the Szlachtowa Formation exposed near Jarabina yielded macrofossils: the bivalve Bositra buchi (Fig. 15A) and ammonite Brasilia (Brasilia) sp. (Fig. 15B); the latter points to an Aalenian age (determined by J. Schlögl).

Oszczypko et al. (2012: p. 436) explain the presence of abundant Middle Jurassic fossils in the Szlachtowa Formation by redeposition during erosion of the Czorsztyn Ridge throughout the Aptian-Albian transition. But there is no reasonable explanation given why these "reworked" fossils represent a relatively narrow time interval (Middle Jurassic, mainly Aalenian-Bajocian: e.g., Švábenická in Oszczypko et al., 2004; Gedl, 2008d; Barski et al., 2012). Moreover, Oszczypko et al. (2012) do not explain why the Szlachtowa Formation contains no traces of typical Upper Jurassic-Lower Cretaceous lithologies (see e.g., Krawczyk and Słomka, 1986, 1987; Krawczyk et al., 1987); they also do not explain how the paper-thin shells of Bositra buchi could be reworked (present in the Szlachtowa Formation, they form a filamentous microfacies in the Opaleniec Formation; e.g., Birkenmajer and Myczyński, 1977; Birkenmajer et al., 2008: fig. 9); there is also no explanation of the presence of Jurassic ammonites in the clayey shale of the Szlachtowa Formation.

Oszczypko et al. (2012) give no explanation of why the Szlachtowa and Opaleniec formations contain no Cretaceous organic-walled dinoflagellate cysts, that are so frequent in true Cretaceous dark-coloured strata of the Pieniny Klippen Belt (Figs. 6-9; see also e.g., Skupien, 2003; E. Gedl, 2007) and the Flysch Carpathians (e.g., Gedl, 1997; E. Gedl, 1999).

Oszczypko et al. (2012: p. 436) pose the question: "Assumption of a Middle Jurassic age for the Szlachtowa and Opaleniec formations is leading to the question: where did the Upper Jurassic-Lower Cretaceous deposits disappear?". But they give the answer themselves by showing the Upper Jurassic to Lower Cretaceous succession of the Grajcarek Unit exposed at Szczawnica-Zabaniszcze (Oszczypko et al., 2012: fig. 4A, C, D): the Sokolica Radiolarite Formation (Bajocian?-Oxfordian?), the Czajakowa Radiolarite Formation (Oxfordian), the Czorsztyn Limestone Formation (Kimmeridgian-Tithonian), the Pieniny Limestone Formation (Tithonian-Barremian), the Kapuśnica Formation (Aptian-Albian) and the Wronine Formation (Albian) overlain by the Hulina Formation (Cenomanian; Fig. 3).

Summarizing, the data presented by Oszczypko et al. (2012) do not allow, in my opinion, acceptance of a Cretaceous age for the Szlachtowa and Opaleniec formations. In my opinion, most of the productive samples that, according to Oszczypko et al. (2012), should witness a Cretaceous age for the strata in question, were collected in fact from other Cretaceous lithostratigraphic units such as the Hulina, Wronine or Malinowa Shale formations (the Szlachtowa Formation does not consist of red shale or green radiolarite). Productive samples are almost always collected from contact zones with Cretaceous units, whereas samples from typical Szlachtowa and Opaleniec formations are barren or contain assemblages non-diagnostic of age. Foraminifera assemblages from many samples show contamination, which is treated by Oszczypko et al. (2012) highly arbitrarily: when highlighted by their opponents as an indication of age-misunderstanding (e.g., Birkenmajer and Pazdro, 1968; Birkenmajer et al., 2008) - this is rejected; when referred to by themselves, even in such evident case as an admixture of Paleogene species - it is suppressed.

\section{CONCLUSIONS}

The Grajcarek Succession exposed above the Pieniny Limestone Formation on the NE bank of the Jarmucki Potok (Zabaniszcze Creek) at Szczawnica-Zabaniszcze consists of the following lithostratigraphic units: the Kapuśnica, Wronine, Opaleniec and Szlachtowa formations. The first two units remain in stratigraphical succession above the Pieniny Limestone Formation. Their dinoflagellate cysts are of Cretaceous age, particularly: Late Barremian-earliest Aptian (top of the Pieniny Limestone Formation), earliest Aptian (Kapuśnica Formation) and Albian? (Wronine Formation). The latter unit contacts tectonically with the superficially very similar Opaleniec Formation. The main difference that allows their distinction is the high carbonate content of the latter (the Wronine Formation consists predominantly of non- or poorly-calcareous shale); this makes the Wronine and Opaleniec formations barely distinguishable in field. But the dinoflagellate cyst content leaves no doubt that the Opaleniec Formation is of Jurassic age: its strata at Szczawnica-Zabaniszcze yielded very rich and well-preserved Late Bathonian assemblages. The Szlachtowa Formation yielded Jurassic assemblages: from Early Aalenian (Late Toarcian?) through Late Aalenian to Early Bajocian. Neither the Szlachtowa Formation nor Opaleniec Formation yielded Cretaceous dinoflagellate cysts that would justify suggesting a Cretaceous age for them.

Acknowledgements. I would like to thank D. Plašienka and M. Barski for critical reading, and to J. Zalasiewicz for linguistic correction of the manuscript. J. Schlögl is kindly acknowledged for taxonomical determination of an ammonite from Jarabina. 


\section{REFERENCES}

Andrusov D. (1929) Notes sur la géologie des Carpathes du Nord-Ouest. IV. Les klippes Piénines. Vestnik Statního Geologického Ústavu SR (Praha), 5 (6): 327-342.

Andrusov D. (1938) Etude géologique de la zone des Klippes internes des Carpathes Occidentales. III-e partie: Tectonique. Rozprávy Statního Geologického Ústavu SR (Praha), 9: 1-135.

Barski M., Matyja B.A., Segit T., Wierzbowski A. (2012) Early to Late Bajocian age of the so called "black flysch" (Szlachtowa Fm.) deposits: implications for the history and geological structure of the Pieniny Klippen Belt, Carpathians. Geological Quarterly, 56 (3): 391-410.

Birkenmajer K. (1977) Jurassic and Cretaceous lithostratigraphic units of the Pieniny Klippen Belt, Carpathians, Poland. Studia Geologica Polonica, 45: 1-159.

Birkenmajer K., (1979) Przewodnik geologiczny po pienińskim pasie skałkowym. Wydawnictwa Geologiczne, Warszawa.

Birkenmajer K. (1986) Stages of structural evolution of the Pieniny Klippen Belt, Carpathians. Studia Geologica Polonica, 88 7-32.

Birkenmajer K., Gedl P. (2004) Dinocyst ages of some Jurassic strata, Grajcarek Unit at Sztolnia Creek, Pieniny Klippen Belt (Poland). Studia Geologica Polonica, 123: 245-277.

Birkenmajer K., GedI P. (2007) Age of some deep-water marine Jurassic strata at Mt Hulina, Małe Pieniny Range (Grajcarek Unit, Pieniny Klippen Belt, West Carpathians, Poland), as based on dinocysts. Studia Geologica Polonica, 127: 51-70.

Birkenmajer K., Myczyński R. (1977) Middle Jurassic deposits and fauna of the Magura Succession, near Szlachtowa, Pieniny Klippen Belt (Carpathians). Acta Geologica Polonica, 27: 387-400.

Birkenmajer K., Pazdro O. (1963) Microfaunal reconnaissance of the Dogger of the Pieniny Klippen Belt (Carpathians) in Poland. Bulletin de l'Académie Polonaise des Sciences, série des sciences géologiques et géographiques, 11: 127-132.

Birkenmajer K., Pazdro O. (1968) On the so-called "Sztolnia beds" in the Pieniny Klippen Belt of Poland (in Polish with English summary). Acta Geologica Polonica, 18: 325-365.

Birkenmajer K., Tyszka J. (1996) Palaeoenvironment and age of the Krzonowe Formation (marine Toarcian - Aalenian), Pieniny Klippen Belt, Carpathians. Studia Geologica Polonica, 109: $7-42$.

Birkenmajer K., Dudziak J., Jednorowska A. (1970) Subsurface geological structure of the northern boundary fault zone of the Pieniny Klippen Belt at Szczawnica, Carpathians (in Polish with English summary). Studia Geologica Polonica, 61: 7-36.

Birkenmajer K., Gedl P., Myczyński R., Tyszka J. (2008) "Cretaceous black flysch" in the Pieniny Klippen Belt, West Carpathians: a case of geological misinterpretation. Cretaceous Research, 29: 535-549.

Blaicher J. (1973) Monografia mikrofauny dolnej kredy jednostk magurskiej. Archiwum Państwowego Instytutu Geologicznego, Kraków.

Błaszyk J. (1968) Ostracods from the Sztolnia Creek profile in the Pieniny Klippen Belt of Poland (in Polish with English summary). Acta Geologica Polonica, 18: 367-373.

Bucefalo Palliani R., Riding J.B. (1997) The influence of palaeoenvironmental change on dinoflagellate cyst distribution. An example from the Lower and Middle Jurassic of Quercy, southwest France. Bulletin du Centre Recherches Elf Exploration Production, 21: 107-123.

Dudziak K. (1986) Calcareous nannoplankton from the Szlachtowa Formation, Jurassic, of Sztolnia Creek, Pieniny Klippen Belt, Carpathians (in Polish with English summary). Studia Geologica Polonica, 88: 135-141.

Duxbury S. (1983) A study of dinoflagellate cysts and acritarchs from the Lower Greensand (Aptian to Lower Albian) of the Isle of Wight, Southern England. Palaeontographica, Abt. B, 186: $18-80$.
Feist-Burkhardt S. (1990) Dinoflagellate cyst assemblages of the Hausen coreholes (Aalenian to early Bajocian), southwest Germany. Bulletin des Centres de Recherches Exploration Production Elf Aquitaine, 14: 611-633.

Feist-Burkhardt S., Monteil E. (1997) Dinoflagellate cysts from the Bajocian stratotype (Calvados, Normandy, Western France). Bulletin du Centre Recherches Elf Exploration Production, 21: 31-105.

Feist-Burkhardt S., Monteil E. (2001) Gonyaulacacean dinoflagellate cysts with multi-plate precingular archaeopyle. Neues Jahrbuch für Geologie und Paläontologie, Abhandlungen, 219: 33-81.

Feist-Burkhardt S., Wille W. (1992) Jurassic palynology in southwest Germany - state of the art. Cahiers de Micropaléontologie, 7: 141-164.

Gąsiorowski S.M. (1962) Aptychi from the Dogger, Malm and Neocomian in the Western Carpathians and their stratigraphical value. Studia Geologica Polonica, 10: 1-151

GedI E. (1999) Lower Cretaceous palynomorphs from the Skole nappe (Outer Carpathians, Poland). Geologica Carpathica, 50: 75-90.

Gedl E. (2007) Lower Cretaceous dinocyst stratigraphy and palynofacies of the Grajcarek Unit, Pieniny Klippen Belt, West Carpathians, Poland. Studia Geologica Polonica, 127: 71-100.

GedI P. (1997) Palynological study of an olistolith from the so-called Sucha formation, Zawoja IG-1 borehole (Flysch Carpathians, Poland): age and palaeoenvironment. Annales Societatis Geologorum Poloniae, 67: 203-215.

GedI P. (2007) Organic-walled Dinoflagellate cysts from some Jurassic and Cretaceous strata of the Grajcarek Unit at Hałuszowa, Pieniny Klippen Belt (West Carpathians, Poland). Studia Geologica Polonica, 127: 101-117.

GedI P. (2008a) Comments for discussion on biostratigraphy of the so-called "black flysch" of the Pieniny Klippen Belt in Poland (in Polish). Przeglad Geologiczny, 56 (3): 212-220.

GedI P. (2008b) The age of the Szlachtowa Formation (the so-called "black flysch") and the Opaleniec Formation (Pieniny Klippen Belt, Poland) based on dinoflagellate cyst studies (in Polish with English summary). Przegląd Geologiczny, 56 (3): 245-252.

Gedl P. (2008c) One more time on the so-called "black flysch" of the Pieniny Klippen Belt in Poland (in Polish). Przegląd Geologiczny, 56 (6): 458-459.

GedI P. (2008d) Organic-walled dinoflagellate cyst stratigraphy of dark Middle Jurassic marine deposits of the Pieniny Klippen Belt, West Carpathians. Studia Geologica Polonica, 131: 7-227.

Głuchowski E.A. (1987) Jurassic and Early Cretaceous Articulate Crinoidea from the Pieniny Klippen Belt and the Tatra Mts, Poland. Studia Geologica Polonica, 94: 1-102.

Głuchowski E.A., Krawczyk A.J., Słomka T. (1983) Isocrinida from the Szlachtowa Formation (Jurassic) of the Pieniny Klippen Belt, Carpathians, Poland. Studia Geologica Polonica, 77: 83-88.

Krawczyk A.J., Słomka T. (1986) Development and sedimentation of the Szlachtowa Formation (Jurassic flysch) east of Szczawnica (Grajcarek Unit, Pieniny Klippen Belt, Carpathians) (in Polish with English summary). Studia Geologica Polonica, 88: 33-134.

Krawczyk A.J., Słomka T. (1987) Exotic rocks from the Szlachtowa Formation (Jurassic flysch) of the Pieniny Klippen Belt, Carpathians (in Polish with English summary). Studia Geologica Polonica, 92: 69-74.

Krawczyk A.J., Muszyński M., Słomka T. (1987) Exotic rock fragments from psammitic rocks of the Szlachtowa Formation (Jurassic flysch) of the Pieniny Klippen Belt, Carpathians (in Polish with English summary). Studia Geologica Polonica, 92: 75-86.

Krawczyk A.J., Krobicki M., Słomka T. (1992) Belemnites from the Szlachtowa Formation (Middle Jurassic), Pieniny Klippen Belt, 
Carpathians. Bulletin of the Polish Academy of Sciences, Earth Sciences, 40: 1-7.

Książkiewicz M. (1972) Tektonika pienińskiego pasa skałkowego. In: Budowa geologiczna Polski. Tom IV. Tektonika, część 3, Karpaty (ed. M. Książkiewicz): 67-119. Wydawnictwa Geologiczne, Warszawa.

Oszczypko N., Malata E., Švábenická L., Golonka J., Marko F. (2004) Jurassic-Cretaceous controversies in the Western Carpathian Flysch: the "black flysch" case study. Cretaceous Research, 25: 89-113.

Oszczypko N., Golonka J., Malata E. (2008) Reply to Comments for discussion on biostratigraphy of the so-called "black flysch" of the Pieniny Klippen Belt in Poland (in Polish). Przegląd Geologiczny, 56 (3): 221-224.

Oszczypko N., Olszewska B., Malata E. (2012) Cretaceous (Aptian/Albian-?Cenomanian) age of "black flysch" and adjacent deposits of the Grajcarek thrust-sheets in the Małe Pieniny Mts. (Pieniny Klippen Belt, Polish Outer Carpathians). Geological Quarterly, 56 (3): 411-440.

Pazdro O. (1979) Microfauna from the Opaleniec Formation (Middle Jurassic), Pieniny Klippen Belt of Poland, Carpathians (in Polish with English summary). Studia Geologica Polonica, 61: 105-128.

Plašienka D., Soták J., Jamrichová M., Halásová E., Pivko D., Józsa Š., Madzin J., Mikuš V. (2012) Structure and evolution of the Pieniny Klippen Belt demonstrated along a section between Jarabina and Litmanová villages in Eastern Slovakia. Mineralia Slovaca, 44: 17-38.

Prauss M. (1989) Dinozysten-Stratigraphie und Palynofazies im Oberen Lias und Dogger von NW-Deutschland. Palaeontographica, Abt. B, 214: 1-124.
Pugaczewska H. (1971) Aalenian Gryphaeinae from the Pieniny Klippen Belt of Poland. Acta Palaeontologica Polonica, 16: 389-399.

Sikora W. (1962) New data on the geology of the Pieniny Klippen Belt. Bulletin de l'Académie Polonaise des Sciences, série des sciences géologiques et géographiques, 10: 203-211.

Sikora W. (1971) Esquisse de la tectogénčse de la zone des Klippes des Pieniny en Pologne d'aprčs de nouvelles données géologiques (in Polish with French summary). Annales de la Société Géologique de Pologne, 41: 221-239.

Skupien P. (2003) Dinoflagellate study of the Lower Cretaceous deposits in the Pieniny Klippen Belt (Rochovica section, Slovak Western Carpathians). Bulletin of the Czech Geological Survey, 78: 67-82.

Stover L.E., Brinkhuis H., Damassa S.P., Verteuil L. de, Helby R.J., Monteil E., Partridge A.D., Powell A.J., Riding J.B., Smelror M., Williams G.L. (1996) Mesozoic-Tertiary dinoflagellates, acritarchs and prasinophytes. American Association of Stratigraphic Palynologists Foundation, Dallas, Texas, 2: 641-750.

Torricelli S. (2000) Lower Cretaceous dinoflagellate cyst and acritarchs stratigraphy of the Cismon APTICORE (Southern Alps, Italy). Review of Palaeobotany and Palynology, 108: 213-266.

Uhlig V. (1890) Ergebnisse geologischer Aufnahmen in den westgalizischen Karpathen. II. Th. Der pieninische Klippenzug. Jahrbuch der geologischen Reichs-Anstalt (Wien), 40 (3-4): 559-824.

Wille W., Gocht H. (1979) Dinoflagellaten aus dem Lias Südwestdeutschlands. Neues Jahrbuch für Geologie und Paläontologie, Abhandlungen, 158: 221-258. 